\title{
16. COMMISSION POUR L'ETUDE PHYSIQUE DES PLANETES ET DES SATELLITES
}

Président: A. Dollfus.

SeCRÉtAIRE: J. H. Focas.

La Commission 16 s'est réunie à Hambourg au cours des sessions suivantes:

Session administrative $I$ : 26 Août 1964: Organisation des Centres de Documentation-

Recherches effectuées à l'aide des documents de ces Centres.

Session administrative II: 26 Août 1964: Programmes d'observations concertées sur les planètes. Session administrative III: i Septembre 1964: Nomenclature et cartographie de la Lune.

Session scientifique I: 26-28 Août 1964: Colloque: 'L'atmosphère de Jupiter.'

Session scientifique II: I Septembre I964: Colloque: 'Nature et structure du sol lunaire.'

\section{Session administrative I}

Le Président a annoncé le décès des membres suivants:

Le Dr M. B. B. Heath, décédé le 2I Novembre I963. Observateur distingué des planètes et surtout de Jupiter, animateur de la British Astronomical Association.

Le Dr E. C. Slipher, Lowell Observatory, décédé le 7 Août I964, après avoir obtenu au cours de 60 ans une collection de photographies planétaires de plus de 10000 clichés, la plus importante du monde. Les Centres de Documentation de l'UAI ont participé à la mise en valeur de cette collection. Une partie de cette oeuvre a déjà été publiée en deux très importants volumes.

Le Dr J. S. Hall accepte de souligner l'importance des deux volumes de l'oeuvre du Dr E. C. Slipher publiés par l'Observatoire Lowell, qui contiennent une grande partie des clichés pris par l'auteur.

\section{ETABLISSEMENT DES CENTRES DE DOCUMENTATION ET D'OBSERVATIONS SUR LES PLANÈTES}

Lors de l'Assemblée Générale de Berkeley en I96I, la Commission avait constitué un Comité I $6 c$ 'Coopération Internationale pour l'Observation des Planètes-International Cooperation for Planetary Observations.'

Les travaux de ce Comité depuis 196I sont résumés par la motion suivante proposée à l'approbation de l'Assemblée:

\section{Motion complémentaire sur la Résolution no. 3 adoptée d̀ Berkeley en $\mathrm{I} 96 \mathrm{I}$ Additional statement on Resolution no. 3 adopted at Berkeley, $196 \mathrm{r}$}

'La Résolution no. 3 adoptée lors de la dernière assemblée de la Commission 16 à Berkeley recommandait l'établissement d'au moins deux centres de données sur les planètes, l'un aux U.S.A., l'autre en Europe, afin de faciliter les recherches sur les planètes nécessitant la consultation de collections de clichés antérieurement éparpillés.

'En conséquence, deux tels Centres sont actuellement en cours de constitution depuis 3 ans, l'un à l'Observatoire Lowell, Flagstaff, Arizona, U.S.A., l'autre à l'Observatoire de Meudon, France.

'Des reproductions et échanges de nombreux documents photographiques sont en cours.' 
'Resolution no. 3 adopted at the last meeting by Commission 16 recommended the establishment of at least two data centres, one in U.S.A., and one in Europe, to facilitate researches on collections of photographic plates on planets, previously scattered in several observatories.

'As a result two such centres have been under development during the past 3 years, one at Observatoire de Meudon, France, and one at Lowell Observatory, Flagstaff, Arizona, U.S.A. Reproduction and active exchanges of photographic data have been initiated.'

Ce choix a été dicté par l'importance de ces établissements scientifiques, par leur longue tradition dans l'étude des planètes et par la valeur des grandes collections de clichés déjà disponibles dans chacun de ces centres.

Le Professeur Kopal suggère que la motion précédente soit complétée en ce qui concerne le groupement des documents sur la Lune et les observations collectives de la surface lunaire sous différentes longitudes. Après une discussion à laquelle prirent part notamment le Professeur Minnaert et le Président, il sembla préférable de limiter la présente motion aux problèmes concernant seulement les planètes.

La motion précédente est adoptée.

\section{Travaux d'organisation des centres}

(a) Le Professeur Hall, Directeur de l'Observatoire Lowell, expose comme suit les problèmes relatifs à l'établissement du Centre de Documentation de l'Observatoire Lowell:

'NASA has awarded the Lowell Observatory two grants in support of the data organization centre to be established at the Lowell Observatory. One of these is to provide a new building for housing the vaults, dark rooms, laboratories which are needed for the collection and scientific use of the data. The second grant is to provide support for the collection of the data and for subsequent research for a period of 3 years beginning I July 1963 .

'About 5000 original plates of Mars at the Lowell Observatory have been evaluated by J. H. Focas acting as liaison between the two centres. The informations are to be filed on cards, together with dates and other pertinent data. About 1300 composites have been made, mostly of Mars.

'For Mars, IBM cards catalogue will be complete in the sense that one card will be partially filled out for each plate. A catalogue will be made of all composites. Exchanges of lists of available data and of photographic reproductions between the data centres have been initiated.

'Further, to the evaluation of approximately 5000 planetary negatives, J. H. Focas carried out a special photometric research of Jupiter and examined 1500 negatives of Mars taken in blue light in the period $1926-63$ on the purpose to study atmospheric formations and transparency of the Martian atmosphere. As far as the personnel of the Lowell Centre is concerned, S. Jones and two assistants are charged with the photographic work. Dr Sinton and Dr Boyce are equally working on the planets. The necessity of competent director for the Lowell data centre is evident.'

(b) Le Président expose les problèmes posés par le Centre de Meudon:

'Le centre a bénéficié de la part de l'UAI d'une subvention de 2000 dollars pour les trois dernières années. L'Observatoire de Paris contribue par la mise à disposition d'un photographe. Un bâtiment particulier est prévu en 1965 pour loger les collections et le centre.

'Les collections de clichés existant à Meudon ont déjà été beaucoup exploitées par des chercheurs ces dernières années.

'Sur la planète Mars, I 500 composites obtenues au Pic du Midi depuis 1941 ainsi que des images de 1909 sont disponibles. L'échelle des clichés-composites est uniformisée à I" par mm. Les collections du Pic du Midi sont complétées par environ Iooo clichés provenant notamment 
du Mont Wilson( R. Leighton), d'Afrique du Sud (W. S. Finsen), Table Mountain Observatory (C. Capen), New Mexico University (B. Smith), Athènes (J. H. Focas), Kwasan, Japon (S. Miyamoto), Lick Observatory (H. M. Jeffers), etc. De plus, en raison des échanges déjà entrepris entre les deux centres, des clichés de Mars de la collection de E. C. Slipher sont consultables à l'Observatoire de Meudon.

'Le Centre de Meudon a bénéficié en outre de collections de clichés planétaires obtenus par F. Quénisset depuis 1903, ainsi qu'environ 600 clichés de Jupiter, une centaine d'images de Saturne et plus de 1000 images de Vénus en lumière visible et ultraviolette en provenance de divers observatoires.'

(c) Le $\mathrm{Dr} \mathcal{F}$. H. Focas expose les problèmes de la liaison et des échanges entre les deux centres de documentation:

'L'organisation des centres est prévue comme suit:

'Envoi des observations aux centres. Les observatoires qui ont accepté leur coopération, jusqu'ici au nombre de 20 , envoient aux deux centres des négatifs originaux, ou leurs copies positives, ou dans certains cas les images compositées.

'A défaut, certains observatoires adressent des copies positives sur papier.

'De plus, les centres reçoivent des observations visuelles, polarimétriques, photométriques, spectroscopiques, pouvant intéresser la Coopération Internationale.

'Echange de documents entre les deux centres: Les négatifs originaux sont copiés en positifs agrandis et échangés entre les deux centres (deux copies par centre). Chaque centre prépare dans la mesure du possible des images composites d'après les négatifs originaux à l'échelle de I" et en échange les copies.

'Les informations relatives à chaque document sont reportées sur cartes perforées et comportent notamment les données géométriques, chronologiques, la qualité photographique et photométrique selon un code convenu.'

\section{TRAVAUX DE RECHERCHES EFFECTUÉS GRÂCE À LA DOCUMENTATION DES CENTRES}

Deux exemples sont donnés de recherches rendues seules possibles par la présence, dans les centres de documentation, d'une grande quantité de clichés recueillis par des observatoires répartis sous différentes longitudes.

(a) A l'Observatoire de Meudon: Grâce au groupement de nouveaux clichés de la planète Mars obtenus lors de l'opposition périhélique de 1956 , le Dr G. de Mottoni a pu compléter l'étude de l'évolution et des déplacements de voiles jaunes exceptionnels apparus dans l'atmosphère de la planète, entre le ${ }_{5}$ Août et la fin Septembre 1956 .

Environ 560 images permirent de dresser six cartes en projection conique centrées sur le pôle austral (qui seront reproduites dans des publications séparées). L'évolution des voiles de poussières a pu être reconstituée. D'après A. Dollfus, les trajectoires semblent de préférence envelopper les taches sombres permanentes du sol. Selon l'analyse théorique du transfert d'énergie, Y. Mintz avait prévu l'existence probable de deux régimes possibles sur la planète Mars, selon les saisons: en hiver, une circulation turbulente du type de celle de notre atmosphère; en été, un régime régulier qui serait alors seulement influencé par les conditions topographiques. Les présentes observations favorisent le flot régulier pendant le printemps martien.

Les données précédentes concernent aussi le travail du Dr A. Ryan dont voici la communication: 
'Formation of the Martian yellow clouds is generally believed to be associated with removal of material from the planetary surface. It is of particular interest that the wind velocity required to remove such material is in part a function of atmospheric pressure. Assuring a reasonable surface model one finds that, should the pressure be $80 \mathrm{mb}$, the required winds are compatible with those observed. Should the pressure be as low as 25 , or $10 \mathrm{mb}$, as recently stated, wind velocities have to be faster than any ever observed. Compatibility for $25 \mathrm{mb}$ could be achieved either if the required high velocity winds exist for so short a time as to have escaped detector, or if they are cyclonic. For $10 \mathrm{mb}$, it appears that only if the winds are cyclonic can compatibility be achieved.'

(b) A l'Observatoire Lowell: Le Dr J. H. Focas a effectué un travail photométrique sur l'activité atmosphérique de Jupiter, couvrant la période I904-63. Ce travail rendu seul possible par la grande quantité des documents groupés, met en valeur les variations périodiques dans l'apparence des bandes et l'activité de celles-ci, et sera résumé plus loin, à l'occasion du colloque sur Jupiter.

\section{Session administrative II}

IIr. COORDINATION DES OBSERVATIONS COLLECTIVES DES SURFACES PLANÉTAIRES

La Commission a coordonné les observations entre différentes stations à l'occasion des phénomènes planétaires exceptionnels ou nécessitant des observations simultanées sous plusieurs longitudes.

\section{x. Programmes achevés}

(a) Etude de la tache temporaire sur Saturne en 1960. Les observations correspondantes, déjà résumées dans le rapport des séances de Berkeley I96I, ont été complètement étudiées. Elles ont prouvé l'existence d'un courant atmosphérique équatorial très rapide dans l'atmosphère de Saturne. Les résultats sont publiés comme suit:

'Mouvement dans l'atmosphère de Saturne en 1960. Observations coordonnées par l'Union Astronomique Internationale' (Icarus, 2, 109, 1963).

(b) Observations de Mercure devant le disque solaire le 7 Novembre I960. Les mesures du diamètre de Mercure lors du passage, recueillies par des méthodes différentes dans cinq observatoires et sommairement résumées dans le rapport des séances de Berkeley 1961,

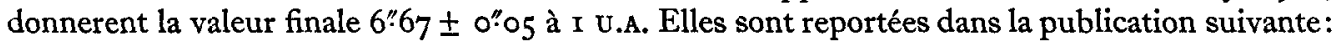

'Mesures du diamètre de Mercure lors de son passage devant le Soleil le 7 Novembre i960Résultats des observations collectives demandées par l'Union Astronomique Internationale' (Icarus, 2, 219, 1963).

Le Dr Rösch ajoute le commentaire suivant:

'Dans un travail qui sera publié dans Icarus, H. Camichel, M. Hugon et J. Rösch ont discuté des effets systématiques entachant par défaut les mesures du diamètre de Mercure faites soit au micromètre à double images, soit par la méthode de Hertzsprung. Cette discussion conduit aux valeurs 6"84 $\pm 0 " 03$ à I U.A. et 5.09 \pm 0.7 pour la densité.'

\section{Programmes d'observations en cours}

(a) Mesures de polarisation sur la surface du disque de Mars

La proportion de lumière polarisée renvoyée par les différentes régions de la surface de Mars varie avec l'angle de phase en déterminant une 'courbe de polarisation' caractéristique de la nature physique du sol et des propriétés de diffusion dans l'atmosphère. 
Les variations de polarisation d'un point à l'autre du disque caractérisent les différentes taches du sol, ainsi que les voiles, brumes ou nuages passagers en suspension dans l'atmosphère.

A la demande de la Commission $\mathrm{r} 6$, de nombreuses mesures de polarisation ont été relevées sur de petites régions de la surface de Mars en 1962 et 1963 grâce au polarimètre à franges de Lyot, aux Observatoires d'Athènes, du Pic-du-Midi et de Harvard. Des mesures de l'ensemble du disque obtenues photoélectriquement en différentes longueurs d'onde à Kiev ont été transmises par le Dr Morozenko.

Les variations locales de polarisation permettent de déceler les évolutions diurnes et progressives des voiles atmosphériques, et en outre de discriminer entre voiles de poussières et nuages de cristaux. L'étude des mesures devrait permettre de préciser la contribution de la diffusion moléculaire et d'améliorer la détermination de la pression atmosphérique.

A la demande du Dr Luplau Janssen, le Président indique que des polarimètres visuels à franges de Lyot sont fabriqués par la Société Française Jobin et Yvon.

Le Dr de Vaucouleurs signale l'importance des déterminations de la pression atmosphérique et le désaccord des méthodes polarimétriques et photométriques avec les résultats spectroscopiques récents.

Le Président résume comme suit les dernières déterminations:

\section{Auteurs}

G. de Vaucouleurs

A. Dollfus

G. Münch

L. Kaplan

I. Spinrad

G. P. Kuiper
Méthodes

Photométrie

Polarimétrie

Spectrographie

Bande du $\mathrm{CO}_{2}$

(Spectrographie

Bande du $\mathrm{CO}_{2}$
Valeurs de la pression atmosphérique

$95 \mathrm{mb}$

$85 \mathrm{mb}$

$25 \mathrm{mb}$

$16 \mathrm{mb}$

Il semble que les déterminations de la pression atmosphérique par mesures polarimétriques puissent maintenant étre améliorées, en tenant compte des connaissances nouvelles acquises sur les impuretés atmosphériques et les faibles voiles de poussières. Des mesures de polarisation nombreuses et bien localisées sur la surface du disque sont désirables. Les grandes collections de clichés photographiques actuellement groupés dans les Centres permettent simultanément une meilleure surveillance de la pureté de l'atmosphère.

\section{(b) Etude photographique de Vénus en ultraviolet}

Les taches mouvantes, claires et sombres, révélées par les photographies se modifient trop rapidement pour que leur évolution puisse être reconstituée par une seule station, dont les observations sont séparées par des intervalles de temps d'environ 24 heures. Il faut la coopération de plusieurs observatoires répartis en longitude.

Les campagnes d'observations en I959 ont été mentionnées dans le rapport des séances de 1961 (Berkeley). La Commission a demandé pour l'élongation du soir de 1962 la participation d'observatoires plus nombreux. Ont bien voulu contribuer aux observations les stations suivantes:

$\begin{array}{lccl}\text { Observatoires } & \text { Longitudes } & \text { Filtres } & \text { Observateurs } \\ \text { Lick } & \mathrm{I} 21^{\circ} \text { Ouest } & \text { UV } & \text { Herbig } \\ \text { Lowell } & 113^{\circ} \text { Ouest } & \text { Bleu } & \text { Giglas } \\ \text { Tucson } & 112^{\circ} \text { Ouest } & \text { UV } & \text { Hartmann } \\ \text { New Mexico } & 105^{\circ} \text { Ouest } & \text { UV } & \text { Smith } \\ \text { Pic du Midi } & 0^{\circ} & \text { UV } & \text { Camichel } \\ \text { Brazzaville (Congo) } & 15^{\circ} \text { Est } & \text { UV } & \text { Boyer } \\ \text { Athènes (Grèce) } & 23^{\circ} \text { Est } & \text { Bleu } & \text { Focas } \\ \text { Kwasan (Japon) } & 135^{\circ} \text { Est } & \text { Bleu } & \text { Miyamoto }\end{array}$


Entre le i6 Mars et le ler Août 1962, près de 300 images ont été obtenues, soit en moyenne 2 images par jour; de nombreuses séries couvrent l'évolution nuageuse pendant plusieurs jours consécutifs avec des intervalles de temps de quelques heures au plus.

En 1963 et 1964, des campagnes d'observations ont été continuées par plusieurs des observiatoires précédents.

Les documents groupés au Centre de Documentation de l'Observatoire de Meudon, et étudiés en particulier par C. Boyer, permettent la reconstitution de l'évolution et établissent leur périodicité.

Le Dr Camichel résume comme suit les travaux effectués par C. Boyer et par lui-même.

'Quelques-unes des taches larges et floues se retrouvent identiques après de longs intervalles de temps, particulièrement celle qui a la forme d'un $\mathrm{Y}$ couché. Souvent les mêmes configurations, comme il a déjà été signalé au Congrès de Berkeley, se retrouvent à intervalles voisins de 4 jours ou des multiples de 4 jours. L'ensemble des documents nouveaux permet d'ajouter les conclusions provisoires que voici:

'Les taches (particulièrement l'Y) se déplacent en gardant la même forme sur une étendue considérable couvrant toute la partie visible de la planète. Le déplacement apparent s'effectue à des vitesses de l'ordre de 200 à $300 \mathrm{~km}$ à l'heure dans le sens rétrograde. On est ainsi conduit à penser, ou bien que l'on observe des phénomènes météorologiques qui présentent une régularité et une stabilité remarquables et assez peu vraisemblables, ou bien que l'on observe une rotation, les taches appartenant au sol ou lui étant liées.

'Mais le déplacement de l'Y est tel qu'il ne semble pas possible d'en rendre compte par une rotation simple; il pourrait correspondre à un mouvement dit "de Poinsot". Ceci n'est pas impossible: si la planète Vénus est entourée de masses fluides importantes, celles-ci peuvent, par leur déplacement, modifier la position des axes principaux d'inertie, et ceci d'autant plus facilement que Vénus est probablement presque sphérique en raison de sa lente rotation.

'Les résultats obtenus jusqu'à présent par la photographie en ultraviolet sont insuffisants pour arriver à une conclusion sûre, et de nouvelles observations faites par des méthodes variées semblent nécessaires.'

La discussion générale met principalement en valeur l'intérêt d'une continuation des observations de cette nature.

\section{Nouvelles propositions d'observations coordonnées}

La Commission a été sollicitée pour aider la coordination de deux programmes d'observations dans le proche avenir:

(a) La Terre passera dans le plan de l'Anneau de Saturne à trois reprises en I966, au dêbut d'Avril, à la fin d'Octobre et au milieu de Décembre. Le Soleil passera dans le plan de l'Anneau au milieur de Juin.

Le Dr Bobrov a demandé que soient organisées des observations photographiques et photométriques nécessaires pour tirer parti de ces jeux d'illumination pour une meilleure connaissance de la structure de l'Anneau.

(b) Pour la coordination des observations physiques de Jupiter avec les mesures radioastronomiques, on propose une cinématographie de la planète Jupiter qui permette de relier des problèmes d'activité générale ou régionale de la planète à courte ou à longue échéance, comme aussi les périodes de rotation de la planète en fonction de la latitude zénographique.

Ce programme a été demandé par le Dr J. H. Focas et le Dr Warwick. 


\section{COMITÉ POUR LA COORDINATION DES OBSERVATIONS ET DES CENTRES DE DOCUMENTATION}

Lors de l'Assemblée de Berkeley r96I, un Comité avait été constitué sous le titre 'Coopération Internationale pour l'Observation des Planètes'.

Les buts de ce Comité ont été définis comme suit:

'Etant donné la nécessité d'étudier dans le temps l'évolution rapide de certains phénomènes planétaires et d'effectuer dans certains cas des surveillances continues, le Comité a pour but d'organiser et de coordonner des observations dans des stations réparties sous différentes longitudes. Le Comité se propose également le groupement dans certains centres de documentation des collections de clichés planétaires actuellement éparpillés dans différents observatoires.'

'Owing to the need for studying rapid changes and evolution on planetary atmospheres or surface features, and to secure continuous records, the Committee will promote and co-ordinate observations between stations at several longitudes in the Earth. The task of the Committee also comprises the collection at the International Data Centres of the existing planetary photographs, at present scattered in several observatories.'

Il a été décidé de maintenir ce Comité dont la nouvelle composition est la suivante: MM. Bobrov, De Mottoni, Dollfus, Focas, Hall, Kopal, Koval, Kuiper, Martynov, Miyamoto, Münch.

Il est proposé que le $\mathrm{Dr}$ A. Dollfus continue à assurer la coordination de ce Comité. Le Dr J. H. Focas a accepté de servir comme secrétaire.

\section{Session administrative III}

Le Comité $16 a$, constitué lors des réunions de Berkeley dans le but d'étudier les problèmes de la nomenclature et de la cartographie de la surface lunaire, est composé comme suit:

A. Dollfus, Z. Kopal, K. Koziel, G. P. Kuiper, D. Martynov, A. A. Mikhailov, M. Minnaert.

Les travaux de ce Comité sont examinés en séance.

Le Dr Arthur, chargé de réviser la nomenclature lunaire à partir des directives générales établies lors de la dernière séance du Comité en I961 donna lecture du rapport suivant:

AN EXTENDED FORM OF BLAGG AND MÜLLER'S SCHEMA OF LUNAR NOMENCLATURE

\section{W. G. Arthur}

The lunar nomenclature proposed by the Lunar and Planetary Laboratory of the University of Arizona is a revised and extended form of that of Blagg and Müller, which was authorized by the Union in 1932. We have attempted to eliminate certain illogical and inconvenient situations in the Blagg and Müller scheme, but all major changes are restricted to the extreme limb regions where the Blagg and Müller scheme, and for that matter, all previous maps, are somewhat unrealistic. The scheme is based on a lengthy and thorough survey of the best available photographs and is embodied in the following documents.

(i) The System of Lunar Craters, Communications of the Lunar and Planetary Laboratory. This work is in four parts with a catalog and map for each of the four lunar quadrants.

(ii) Lunar and Planetary Designations, Arthur and Agnieray, University of Arizona Press. A two-color map in four parts.

(iii) The Rectified Lunar Atlas, Whitaker et al. University of Arizona Press. This gives the names but not the letters. 
(iv) The L.A.C. lunar topographic maps at $1: 1000000$ of the Aeronautical Chart and Information Center of the U.S. Air Force. These are available by subscription.

The above indicates that the proposed scheme is not subject to the drawback of limited distribution, which somewhat hampered the diffusion and acceptance of the Blagg and Müller nomenclature.

As already stated, no major changes were made in the central areas of the disk, except the deletion of a few names which were duplicated elsewhere. In these areas we merely intensified the existing scheme by adding additional letters. The situation near the limb is basically different in that recent intensive cartographic work, coupled with a changeover to conformal projection, makes the Blagg and Müller scheme quite inadequate for contemporary lunar cartography. To eliminate some serious and widespread difficulties, some 60 new names were added in the extreme limb regions. Almost all of these fall in areas which are very poorly represented in all the older maps.

The demands of tradition and continuity were given full weight throughout, even though these often prevented the development of a completely logical scheme of lunar nomenclature.

Table I.

\section{New names}

\begin{tabular}{|c|c|c|c|c|}
\hline \multirow{5}{*}{$\begin{array}{l}\text { Name } \\
\text { Abel } \\
\text { Amundsen } \\
\text { Aston } \\
\text { Baade }\end{array}$} & \multicolumn{2}{|c|}{$\begin{array}{l}\text { Approximate position } \\
\text { of center }\end{array}$} & $\begin{array}{l}\text { Diameter } \\
\text { (Unit } 0.001 R \text { ) }\end{array}$ & Previous identifications \\
\hline & $85^{\circ}: 5 \mathrm{E}$ & $34^{\circ} 5 \mathrm{~S}$ & 50 & Abel (Franz 225) \\
\hline & $93^{\circ} \circ \mathrm{E}$ & $84^{\circ} \circ \mathrm{S}$ & 55 & Amundsen (Wilkins and Moore) \\
\hline & $87^{\circ} 5 \mathrm{~W}$ & $33^{\circ} \circ \mathrm{N}$ & 25 & Ulugh Beigh E (IAU I $897 a)=($ Franz 795$)$ \\
\hline & $82 \div 5 \mathrm{~W}$ & $45^{\circ} \circ \mathrm{S}$ & 26 & $\begin{array}{l}\text { Inghirami D (IAU 225I) }=\text { Hall }(\text { Franz } \\
90 I)\end{array}$ \\
\hline Balboa & $83^{\circ} \cdot 5 \mathrm{~W}$ & $19 \circ 0 \mathrm{~N}$ & 40 & - \\
\hline Balmer & $70 \% \mathrm{E}$ & $20: 0 \mathrm{~S}$ & 75 & - \\
\hline Banachiewicz & $80^{\circ} 5 \mathrm{E}$ & $5^{\circ} \cdot 5 \mathrm{~N}$ & 63 & - \\
\hline Barnard & $86^{\circ} 5 \mathrm{E}$ & $29^{\circ} 5 \mathrm{~S}$ & 60 & - \\
\hline Belkovich & $87^{\circ} \circ \mathrm{E}$ & $6 I^{\circ} \cdot 5 \mathrm{~N}$ & 105 & - \\
\hline Bohr & $86^{\circ} 5 \mathrm{~W}$ & $12^{\circ} \cdot 5 \mathrm{~N}$ & 50 & - \\
\hline Boltzmann & $96^{\circ} \circ \mathrm{W}$ & $75^{\circ} 5 \mathrm{~S}$ & 40 & - \\
\hline Boole & $85^{\circ} \circ \mathrm{W}$ & $64^{\circ} \circ \mathrm{N}$ & 37 & - \\
\hline Boss & $89^{\circ} \cdot 5 \mathrm{E}$ & $46: 0 \mathrm{~N}$ & 27 & - \\
\hline Brianchon & $85 \div \mathrm{W}$ & $74^{\circ} 5 \mathrm{~N}$ & 72 & $\begin{array}{l}\text { Carpenter C (IAU I695) } \\
=\text { Anaximander d (Franz 547) }\end{array}$ \\
\hline Bunsen & $85^{\circ} 5 \mathrm{~W}$ & $4 I \div 0 \mathrm{~N}$ & 44 & - \\
\hline Byrd & $10: 0 \mathrm{E}$ & $85^{\circ} \circ \mathrm{N}$ & 52 & Gioja A (IAU ror 8a) \\
\hline Cannon & $8 I^{\circ} 5 \mathrm{E}$ & $20 \div 0 \mathrm{~N}$ & $3 \mathbf{I}$ & Alhazen F (IAU 25) \\
\hline Cremona & $86^{\circ} \circ \mathrm{W}$ & $67^{\circ} \cdot 5 \mathrm{~N}$ & 55 & - \\
\hline Dalton & $84^{\circ} \cdot 5 \mathrm{~W}$ & $\mathbf{I} 7^{\circ} \circ \mathrm{N}$ & 35 & - \\
\hline Desargues & $73^{\circ} \cdot 5 \mathrm{~W}$ & $70.5 \mathrm{~N}$ & 55 & $\begin{array}{l}\text { Anaximander (IAU I693) = Anaximander } \\
\text { p (Franz 555) }\end{array}$ \\
\hline De Sitter & $38 \% \mathrm{E}$ & $79^{\circ} 5 \mathrm{~N}$ & 37 & Euctemon J (IAU 999c) \\
\hline Drygalski & $82 \div \% \mathrm{~W}$ & $79^{\circ} 5 \mathrm{~S}$ & 97 & $\begin{array}{r}\text { Casatus G (IAU 3294a)= Drygalski (Fauth) } \\
=\text { Cabeus (Franz 839)= Casatus (Schr.) }\end{array}$ \\
\hline Dubiago & $70: 0 \mathrm{E}$ & $4: 5 \mathrm{~N}$ & $2 \mathrm{I}$ & Neper A (IAU 7) \\
\hline Eddington & $72 \div 0 \mathrm{~W}$ & $22: 0 \mathrm{~N}$ & 77 & Otto Struve A (IAU 1902) \\
\hline Einstein & $88{ }^{\circ} \mathrm{W}$ & $16{ }^{\circ} 5 \mathrm{~N}$ & 100 & - \\
\hline Fermi & $89^{\circ} 5 \mathrm{~W}$ & $7: 5 \mathrm{~N}$ & 48 & - \\
\hline Gibbs & $84^{\circ} 5 \mathrm{E}$ & $18: 5 \mathrm{~S}$ & 40 & Hecataeus D (IAU 4752) \\
\hline Gilbert & $76^{\circ} \cdot 5 \mathrm{E}$ & $3{ }^{\circ} 5 \mathrm{~S}$ & 63 & - \\
\hline
\end{tabular}


Table I (continued)

New names

Name

Gill

Goddard

Hale

Hamilton

Hartwig

Hayn

Hedin

Hermite

Hubble

Jansky

Jeans

Kapteyn

Krasnov

Lamarck

Lamé

Langley

Liapunov

Lyot

Markov

Moseley

Nansen

Pascal

Peary

Planck

Poncelet

Rayleigh

Riemann

Röntgen

Russell

Schlüter

\section{Scott}

Shaler

Stefan*

Stokes

Sylvester

Volta

Wright

Joliot-Curie
Approximate position of center

$77^{\circ} \circ \mathrm{E}$

$63^{\circ}: 5 \mathrm{~S}$

$89^{\circ} \circ \mathrm{E}$

$90: 0 \mathrm{E}$

$84 \circ \mathrm{E}$

$15^{\circ} \circ \mathrm{N}$

$74^{\circ} 5 \mathrm{~S}$

$42^{\circ} 5 \mathrm{~S}$

$80: 5 \mathrm{~W}$

$6.5 \mathrm{~S}$

$84^{\circ} \mathrm{O} \mathrm{E}$

$76 \div 5 \mathrm{~W}$

$80 \% 0 \mathrm{~W}$

$86^{\circ}{ }_{5} \mathrm{E}$

$64^{\circ} 5 \mathrm{~N}$

$3 \% \circ \mathrm{N}$

$86^{\circ} \circ \mathrm{N}$

$22: 0 \mathrm{~N}$

$90: 0 \mathrm{E} \quad 8: 5 \mathrm{~N}$

$94^{\circ} \circ \mathrm{E}$

$70^{\circ} \mathrm{E}$

$80 \% \mathrm{~W}$

$70^{\circ} \circ \mathrm{W}$

$64^{\circ} 5 \mathrm{E}$

$86{ }^{\circ} 5 \mathrm{~W}$

90:0 E

$84^{\circ} \circ \mathrm{E}$

$62^{\circ} \cdot 5 \mathrm{~W}$

9I $\circ \mathrm{OW}$

88:0 E

$68: 5 \mathrm{~W}$

$57^{\circ} \mathrm{OS}$

$10^{\circ} 5 \mathrm{~S}$

$30: 0 \mathrm{~S}$

$22^{\circ} 5 \mathrm{~S}$

$14^{\circ} 5 \mathrm{~S}$

$51 \% \mathrm{~N}$

$26^{\circ} 5 \mathrm{~N}$

$50^{\circ} 5 \mathrm{~S}$

$53^{\circ} 5 \mathrm{~N}$

$20^{\circ} \circ \mathrm{N}$

$80: 5 \mathrm{~N}$

$74^{\circ} 5 \mathrm{~N}$

$20 \div 0 \mathrm{E}$

$87^{\circ} 5 \mathrm{~N}$

$87^{\circ} \circ \mathrm{W}$

$8 \circ \mathrm{N}$

$54^{\circ} \circ \mathrm{W}$

$89^{\circ} 5 \mathrm{E}$

$87^{\circ} 5 \mathrm{E}$

$89: 0 \mathrm{~W}$

$75^{\circ} 5 \mathrm{~W}$

$83^{\circ} 5 \mathrm{~W}$

$75^{\circ} 5 \mathrm{~N}$

$29^{\circ} \circ \mathrm{N}$

$39^{\circ} 5 \mathrm{~N}$

$33^{\circ} \circ \mathrm{N}$

$26^{\circ} 5 \mathrm{~N}$

$6 \% 0 \mathrm{~S}$

$47^{\circ} \circ \mathrm{E}$

$82: 5 \mathrm{~S}$

$33^{\circ} \circ \mathrm{S}$

$72^{\circ} \circ \mathrm{S}$

$52^{\circ} \mathrm{ON}$

$82^{\circ} \cdot 5 \mathrm{~N}$

$53^{\circ} 5 \mathrm{~N}$

$3 \mathrm{I}^{\circ} 5 \mathrm{~S}$

$25^{\circ} 5 \mathrm{~N}$

$89^{\circ} \circ \mathrm{W}$

$79^{\circ} 5 \mathrm{~W}$

$85^{\circ} \circ \mathrm{W}$

$86^{\circ} 5 \mathrm{~W}$

$93^{\circ} \circ \mathrm{E}$
Diameter

(Unit $0.001 R$ )

35

43

48

32

50

46

74

65

42

35

50

29

23

55

46

37

36

63

24

45

60

63

50

45

40

52

60

56

55

50

60

$$
22
$$

78

35

35

65

22

82

*Possibly not a true formation.

-

Mare Marginis k (Franz 1274)

Marinus K (IAU 4559a) = Kelvin (Franz 212)

Possibly Riccioli E (IAU 1964)

Strabo G (IAU 424e)

Sven Hedin (Fauth)

Plutarch A (IAU 26a)=Plutarch (Franz 48r)

Mare Australe q (Franz 1357)

Lapeyrouse B (IAU 4769)

Lagrange F (IAU 2228) $=($ Franz 837$)$

Southern part of Darwin (IAU 208r)

Vendelinus C (IAU 4699)

Regnault (Schm.)

Timoleon (Schm.)

Brisbane G (IAU 4540b)

Oenopides A (IAU I7I3)

Contains Franz's points 468 and 469

Carpenter D (IAU 136I and 1694)= Anaximander c (Franz 546)

Gioja B (IAU IoI $8 b$ )

Anaximenes F (IAU r 359a) $=($ Franz 562)

-

-

Northern part of Otto Struve (IAU r 90I)

Malvasia (Schr.) Floor contains Mare Hiemis (IAU 1975a). Possibly= Riccioli A (IAU I962)

Scott (Wilkins and Moore)
-

-

Philolaus p (Franz 730)

-

Note: Floor contains Mare Novum (IAU I 40a), which is Joliot-Curie of the Soviet Lunik III photography.

\section{Explanation of symbols}

IAU Blagg and Müller, Named Lunar Formations, I 935

Schm. Schmidt, J., Charte der Gebirge des Mondes, I 878

Schr. Schröter, Selenotopographische Fragmente, I79r and 1802

$R=$ lunar radius 


\section{Table 2}

\section{Nomenclature revisions}

Deletions

Reinstatement

Additions (see also

Table I)

Changed outlines

Changed identifications

Spelling changes etc.

Latinizations
J. Cassini, Mare Novum, W. Pickering, Schneckenberg

Montes Rook

Rupes Cauchy, Rupes Kelvin, Rupes Liebig, Vallis Baade, Vallis Inghirami, Mare Cognitum

Anaximander, Darwin, Hecateus, Meton, Struve

Brisbane, Regnault, Ulugh Beigh

La Caille, La Condamine, La Hire, La Pérouse, Le Gentil, Le Monnier, Le Verrier, Regnault, Mare Struve, Struve

Mons Argaeus, Montes Apenninus, Montes Carpatus, Montes Caucasus, Montes Cordillera, Montes D'Alembert, Montes Doerfel, Montes Haemus, Montes Harbinger, Montes Hercynii, Montes Jura, Montes Leibnitz, Montes Pyrenaeus, Montes Recti, Montes Riphaeus, Montes Rook, Montes Taurus, Montes Teneriffe, Vallis Alpes, Vallis Rheita, Vallis Schröteri, Rupes Altai, Rupes Cauchy, Rupes Recta, Rima Ariadaeus, Rima Byrgius, Rima Hyginus, Rima Sirsalis, Prom. Fresnel, Prom. Kelvin.

Une discussion générale a lieu à laquelle participent notamment MM. Arthur, Dollfus, le Père Heyden, Hopman, Kopal, Martynov, Menzel, Rackham, Rösch, Shoemaker, Tombaugh, Wildt.

Il est recommandé d'éviter de faire précéder les noms propres par les initailes de prénoms lorsque celles-ci ne sont pas nécessaires.

Le rapport précédent est adopté.

L'impact de la sonde spatiale Range VII dans la région sombre lunaire elliptique comprise entre les cratères Guéricke, Bompland, Darney et Montes Riphaeus a attiré l'attention sur le fait que cette mer n'était pas clairement dénommée.

Le Professeur Kuiper propose deux noms possibles: Mare Exploratum ou Mare Cognitum. Après une attentive discussion, la désignation Mare Cognitum est retenue.

Le comité 'Nomenclature et Cartographie de la Surface Lunaire' est maintenu avec sa composition initiale complétée par le Dr Arthur.

\section{Session scientifique I \\ L'ATMOSPHERE DE JUPITER \\ 1. Rapid changes in the position and appearance of Fovian features}

\section{B. A. Smith}

Since I962, New Mexico State University Observatory has been conducting a photographic observational study of Jupiter, with the more thorough coverage beginning in July I963. As part of this program, Jupiter is photographed in blue, yellow and red light on every possible night. Near opposition several sets of plates may be taken on a single night.

This survey has detected many rapid changes in the position and appearance of atmospheric features. On $24-25$ October 1963 , a dramatic change in the appearance of an equatorial zone bright cloud (longitude $275^{\circ}$, System I) was observed to take place within 20 hours. The area involved was some 300 million square kilometers. Precision measurements of the position of the Red Spot on photographic plates have been made by E. J. Reese. From plates taken since I962, Reese has found many discontinuities in the slow, nearly-linear drift of the Red Spot in 
System II. The frequency of these discontinuities and the accelerations of the Red Spot are of particular interest.

Nightly observations of a given Jovian longitude can, of course, be made only at opposition time from a single observatory. It is therefore recommended that several observatories at scattered terrestrial longitudes take part in a cooperative program for the study of rapid changes in Jovian features.

\section{Sudden changes in the motion of Jupiter's Great Red Spot during 1962}

\section{B. M. Peek (presented by J. H. Focas)}

Fifty-three determinations of the System II longitude of the centre of the Great Red Spot obtained during the last 4 months of 1962 , by E. J. Reese, B. M. Peek, J. Meeus, W. E. Fox and F. Parncott have been plotted and analysed.

The observations indicate, apparently conclusively, that within 3 or 4 weeks, centred about October 20, the Red Spot, whose System II longitudes was steady both previously and subsequently, underwent a rapid displacement amounting to something of the order of five degrees. The dates of October Io and 31 mark approximately the beginning and the end of the abnormal drift.

\section{Changements rapides dans la région de la Tache Rouge en $1962-63$}

\section{F. H. Focas}

Le phénomène du déplacement anormal de la Tache Rouge en longitude au mois d'Octobre I962, semble être étroitement lié à l'évolution d'une forte activité dans la zone tempérée Sud de la planète. L'activité en question, sous forme de taches brillantes, voiles et filaments sombres, se propagea le long d'un axe correspondant à l'emplacement de la composante australe de la Bande Equatoriale Sud, en sens opposé à la direction de rotation de la planète (longitudes croissantes). Le déplacement anormal de la Tache Rouge a été noté lorsque l'activité en question a atteint la région de la Tache Rouge.

\section{Etude photographique de la surface de Fupiter au Pic du Midi}

\section{A. Dollfus}

Depuis 196r le nouveau réflecteur de $107 \mathrm{~cm}$ installé au Pic du Midi pour les études des surfaces planétaires à haute résolution permit de premiers essais sur Jupiter; le miroir était encore provisoirement diaphragmé à $70 \mathrm{~cm}$. Ont pris part à ces premières observations notamment MM. H. Camichel, E. Maurice, M. Marin, A. Dollfus.

A la faveur des nuits de bonnes images fréquemment rencontrées au Pic du Midi, les quatre principaux satellites montrent en permanence les taches de leurs surfaces; la résolution effective était voisine de $0^{\prime \prime 2}$ et une cartographie améliorée de ces satellites est entreprise. Les clichés en lumière jaune (environ 50 en 1961 et 70 en I962) ont montré les taches sur Ganymède et Io, et des structures fines inhabituelles sur le disque même de Jupiter. Les images sont mesurées et redessinées sous forme de planisphères successifs, en projection de Mercator; ces cartes montrent l'évolution des taches claires et sombres, la durée quelquefois très brève des formations petites, et leurs déformations résultant des courants rapides.

Ces photographies étalonnées très fines ont été obtenues à travers différents filtres colorés, en particulier dans l'ultra-violet jusqu'à $3250 \AA$ à travers des filtres à liquide. Dans l'infrarouge, les clichés obtenus sur plaques Kodak $Z$ hypersensibilisées à l'ammoniac donnent une longueur d'onde effective de $8800 \AA$; l'assombrissement du bord du disque devient alors très 
prononcé, les deux régions polaires se montrent très sombres et les bandes habituelles ont presque complétement disparu.

Ces recherches seront développées, et probablement encore trés améliorées à partir de 1964 , alors que le télescope sera utilisé dans les excellentes conditions atmosphériques du Pic du Midi avec sa pleine ouvertude de $107 \mathrm{~cm}$.

\section{Cycles of atmospheric activity on fupiter \\ (Period 1904-63)}

\section{H. Focas}

Sixty-four negatives of Jupiter, taken by E. C. Slipher during the period 1904-63, have been studied photometrically this year at the Lowell Observatory, for the determination of the varying apparent amount of dark matter in the jovian atmosphere, as a criterium of atmospheric activity.

Data resulting from microphotometer scannings along the central meridian of the planet, give after integration for the whole planet the following periodicities and order of magnitude of a coefficient ' $R$ ' $\dagger$ of atmospheric activity during the period $1904-63$ :

Periodicities:

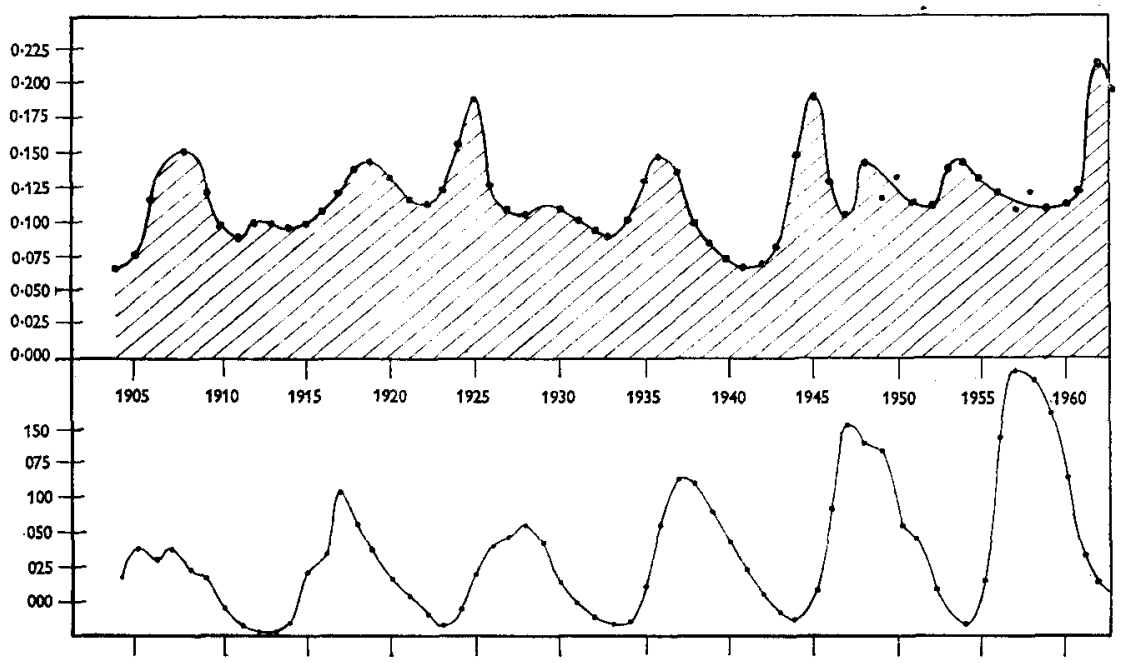

Fig. I: Evolution of the total atmospheric activity of fupiter from 1904 to 1963 . (Total activity for the spherical zone $\varphi=-45^{\circ}$ to $+45^{\circ}$ of zenographical latitude and $L=0^{\circ}$ to $360^{\circ}$.) Top curve: coefficient ' $R$ ' of planetary activity; bottom curve: Wolf number of solar activity.

\section{Whole Planet:}

Cycle I: $1908-25$ period I7 years between two primary maxima.

" II: $1925-45 \quad$ " 20 " , ", ", ", ", "

"III: $1945-62 \quad$ " I7 " " " " ,

$\dagger$ The coefficient of activity ' $R$ ' is the ratio between the shaded (belted) area and the area corresponding to the spherical zone $-45^{\circ}$ to $+45^{\circ}$ of zenographical latitude, within which the activity is measured, taken as a constant area. (Focas, J. H., Banos, C., Ann. Astrophys., 27, 36, 1964.) 


\section{Southern hemisphere:}

Cycle I: $1908-25$ period 17 years between two primary maxima.

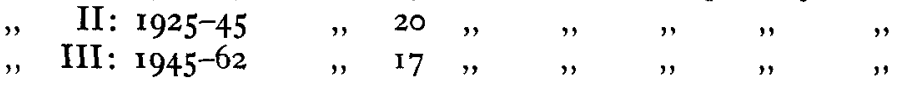

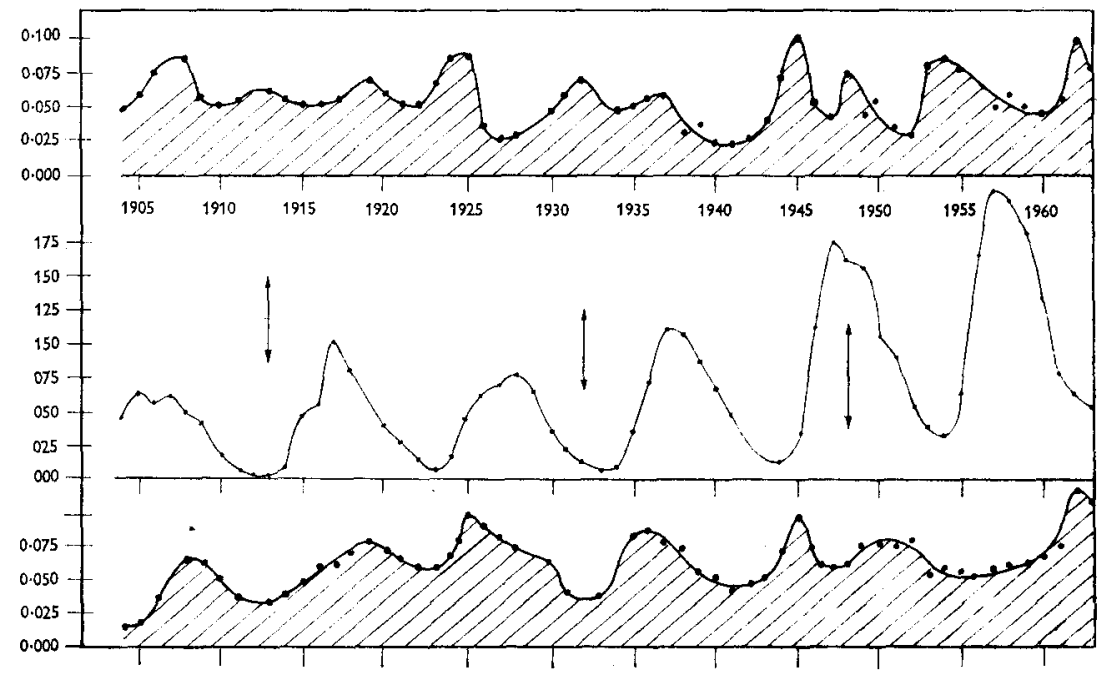

Fig. 2 : Evolution of atmospheric activity of both hemispheres of fupiter. Top curve: southern hemisphere ( $\mathrm{R}$ in ordinates); bottom curve: northern hemisphere ( $\mathrm{R}$ in ordinates); middle curve: solar activity (Wolf number in ordinates).

\section{Northern hemisphere:}

Maxima of activity are in general noted by intervals of 6 to I I years. The $17-20$ years cycle as above, is hardly suspected, the amplitude between primary and secondary maxima being very small. Maxima which can be considered as primary ones, coincide with primary maxima of the southern hemisphere. One secondary maximum is contained between two primary maxima in the northern hemisphere. To the first secondary maximum in the southern hemisphere, corresponds a minimum in the northern hemisphere.

\section{Activity}

There is an asymmetry in the frequency of manifestation of the activity between the two hemispheres.

The activity in the southern hemisphere seems to follow a 17-20 years cycle.

The activity in the northern hemisphere, for a good part, seems to follow an I I years cycle or shorter.

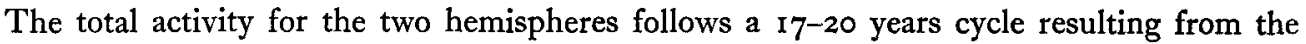
combined activity in the two hemispheres.

The apparent amount of dark matter is slightly greater in the northern hemisphere.

The southern hemisphere is more cataclysmic than the northern.

Some concordance between solar and jovian activities can be suspected. 


\section{Some considerations on the optical properties of the upper atmosphere of Jupiter}

\section{G. Teifel (presented by D. Ya. Martynov)}

It is known that a layer of atmosphere over the cloud surface of Jupiter is responsible for the refraction phenomena and molecular absorption. Almost all the observational information about the chemical composition and physical properties of Jovian atmosphere is connected with that layer or visible surface of the cloud cover of the planet. The interpretation of many observational data depends for the most upon our conception of the structure of upper layers of Jovian atmosphere. At present there is no sufficient complex of the information in our disposition for such conception to be certain, but the available observational data, in particular those obtained in the Astrophysical Institute of the Kazakh Academy of Sciences, Alma-Ata, makes it possible to form some idea of the optical properties of the upper atmosphere of Jupiter.

A photometric study of Jupiter in the different spectral regions showed that $(a)$ the contrast of dark and bright zones of the cloud cover increases from red light to violet, $(b)$ the decreasing of the relative brightness towards the limb varies insufficiently in bright zones and becomes smaller for dark belts in blue and violet. These properties are in a good agreement with the theoretical calculations for the cloud layer with the infinite optical thickness and with the true absorption which increases towards the short wavelengths.

The overcloud atmosphere is not shown photometrically and apparently does not contain aerozol particles. Its transparency depends of only the chemical composition and the density of gaseous medium.

The ratio of air masses of the clear gaseous layer of Jovian atmosphere and clear atmosphere of the Earth is

$$
\frac{M_{\mathrm{J}}}{M_{\mathrm{T}}}=P_{\mathrm{c}} \frac{g_{\mathrm{T}}}{g_{\mathrm{J}}}\left(0.23 D_{\mathrm{H}_{\mathrm{s}}}+0.017 D_{\mathrm{He}}\right)
$$

where $P_{\mathrm{c}}$ is the total pressure on the cloud top (in atmospheres), $g$ the gravitational acceleration, $D_{\mathrm{H}_{2}}$ and $D_{\mathrm{He}}$ the relative abundances of hydrogen and helium by masses in Jovian atmosphere.

The optical thickness of the overcloud atmosphere in the continuum in this case is

$$
\tau_{\mathrm{c}}=\frac{M_{\mathrm{J}}}{M_{\mathrm{T}}} \tau_{\mathrm{T}}
$$

G. Kuiper gave an estimation of the pressure on the cloud top for the model ' $b$ ' as two atmospheres (r). However, he supposed that all observable absorption in the bands of $\mathrm{CH}_{4}$ and $\mathrm{NH}_{3}$ is formed only in the overcloud gas layer. In fact, the molecular absorption may as well take place within the cloud layer possibly being there even more effective than the absorption in the overcloud layer as a result of the multiple scattering.

The latter circumstance is obvious from the observable invariability of the intensity of methan absorption bands in the different parts of the Jupiter's disk. The Table $\mathrm{I}$ shows the equivalent width of $\mathrm{CH}_{4} 6190 \AA$ band is practically invariable (within 10 per cent). If the absorption bands were formed only in gas layer over the cloud top the equivalent width of them should increase from the centre of the Jupiter's disk towards the limb, at least by the factor of 2 .

The measurements of the intensity of the bands $\mathrm{CH}_{4} 5430 \AA$ and $6190 \AA$ made earlier along the equator of Jupiter took the same results (2).

It is necessary to note that the polar regions of Jupiter known as the sources of the anomalous polarization showed no pecularities in the molecular absorption as compared with the another zones of Jupiter's disk. Apparently it is no reason to suppose that over the polar regions of Jupiter the cloud cover is absent or lies sufficiently lower in comparison with another latitudinal zones of the cloud layer. 


\section{Table I}

\begin{tabular}{|c|c|c|}
\hline \multicolumn{3}{|c|}{$\begin{array}{l}\text { The equivalent width } W_{\mathrm{b}} \text { of } \mathrm{CH}_{4} 6 \mathrm{rgo} \AA \text { band at the } \\
\text { different latitude zones of Jupiter's disk in } 1963\end{array}$} \\
\hline Zone & $W_{\mathrm{b}}$ & $\begin{array}{l}\text { Number of the } \\
\text { spectrograms }\end{array}$ \\
\hline SPR & $19.5 \AA$ & I7 \\
\hline STB & $20.0 \AA$ & I7 \\
\hline $\mathrm{STrZ}$ & I $8.5 \AA$ & 17 \\
\hline SEB & $20.4 \AA$ & 17 \\
\hline NEB & $20.4 \AA$ & 17 \\
\hline NTrZ & I9. I $\AA$ & 17 \\
\hline NTZ & $18.6 \AA$ & I7 \\
\hline NPR & $18.3 \AA$ & 17 \\
\hline
\end{tabular}

Two-layers model of the absorbing atmosphere accounts satisfactory for the invariability of the $\mathrm{CH}_{4}$ bands intensity on the disk of Jupiter. The ratio of the intensities in the centre of the absorption band $I_{\mathrm{b}}$ and in the neighbouring region of the continuum $I_{\mathrm{c}}$ is

$$
\frac{I_{\mathrm{b}}}{I_{\mathrm{c}}}=\frac{\lambda_{\mathrm{b}}}{\lambda_{c}}\left[\frac{\varphi_{\mathrm{b}}(\eta)}{\varphi_{\mathrm{c}}(\eta)}\right]^{2} e^{-\frac{2 \tau_{\mathrm{b}}}{\eta}}
$$

where $\varphi_{\mathrm{b}}(\eta)$ and $\varphi_{\mathrm{c}}(\eta)$ are the Ambartsumian functions (3). $\lambda_{\mathrm{c}}=\frac{\sigma}{\sigma+\alpha}, \lambda_{\mathrm{b}}=\frac{\sigma}{\sigma+\alpha+\alpha_{\mathrm{m}}}$, $\sigma$ is the scattering coefficient, $\alpha$ is the coefficient of true continuous absorption within the cloud layer, $\alpha_{m}$ is the coefficient of the methan absorption, $\tau_{b}$ is the optical thickness of the overcloud atmosphere in the centre of the methane absorption band. For the cloud layer of Jupiter in the continuum near $\lambda 6000 \AA, \lambda_{c}$ may be adopted as 0.97 according to the measurements of the brightness distribution on the planetary disk. Several variants-for different $\lambda_{b}$ and $\tau_{b}$-have been examined. Certain combinations of those quantities appeared to give the ratio $I_{\mathrm{b}} / I_{\mathrm{c}}$ which is practically invariable on planetary disk for $r / R$ as large as 0.9 . The variant corresponding to $\lambda_{b}=0.95$ and $\tau_{b}=0.03$ is in the best agreement with the measurements of the depth of band $\mathrm{CH}_{4} 6190 \AA$. In this case the calculated ratio $I_{\mathrm{b}} / I_{\mathrm{c}}$ is equal to the observed one with the simultaneous realization of the condition of invariability of the absorption intensity on the disk. Taking into consideration a true accuracy of measurements, we took $\tau_{b}=0.03 \pm 0.02$. This $\tau_{\mathrm{b}}$ is essentially less than $\tau_{\mathrm{b}}^{\prime}$ obtained from the model with one absorbing layer $\left(\tau_{\mathrm{b}}^{\prime}=0 \cdot \mathrm{I} 2\right)$. Thus the usually adopted abundance of methan (according Kuiper (r) it is $15000 \mathrm{~cm}$ atmospheres within the overcloud atmosphere) has to be reduced by a factor 3 to 4 . The same is concerned to the other gaseous components of the Jovian atmosphere.

That will not influence on the value of adiabatic lapse rate of the temperature because the relative abundances of the gases will remain the same. The calculations of the temperature gradient carried out by the author using the data of the radiometric measurements by Murray and Wildey (4) lead to the mean value

$$
\frac{\mathrm{d} T}{\mathrm{~d} h}=4.3 \times 10^{-5}{ }^{\circ} \mathrm{K} \mathrm{cm}^{-1}
$$

This value practically coincide with that calculated by Kuiper for the chemical composition of Jovian atmosphere which was suggested by him for the model ' $b$ '.

The atmospheric pressure near the upper boundary of the cloud layer also has to be reduced. The partial pressure of the methan at normal conditions (taking into account the absorption within a cloud layer) equals to

$$
p_{\mathrm{m}}=2.8 \mathrm{~g} \mathrm{~cm}^{-2}
$$


instead of the value $10.7 \mathrm{~g} \mathrm{~cm}^{-2}$ that was obtained by Kuiper. The total atmospheric pressure will be

$$
p_{\mathrm{a}}=535 \mathrm{~g} \mathrm{~cm}^{-2}
$$

for the chemical composition according to the model ' $b$ '. Thus the total pressure at the cloud top on Jupiter equals only about 0.5 atmospheres. Now the optical thickness of the atmosphere over the cloud top is

$$
\tau_{\mathrm{c}}=0.013 \tau_{\oplus}
$$

where $\tau_{\oplus}$ is the optical thickness of the Earth's atmosphere which equals according to van de Hulst (5) 0.474 at $\lambda 353 \circ \AA$. The optical thickness of the upper atmosphere of Jupiter along the visible spectrum except the molecular bands is less than 0.01 .

In the other cases of the chemical composition of Jovian atmosphere the results will be not essentially different from those mentioned above.

The nature of the cloud cover of Jupiter is so far vague. The hypothesis on the cristallic ammonia is most probable but it does not give the explanation of the differences of the albedo and colours of various zones and features of the cloud surface of Jupiter. The study of the continuous spectrum permit to discover the fairly considerable absorption in the near ultraviolet. According to the author's observations this absorption is characterized by the following

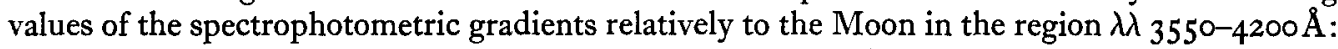

$$
\begin{array}{ll}
G_{U}=\mathrm{I} \cdot 1 \mathrm{I}-\mathrm{I} \cdot 25 & \mathrm{I} 962 \text { September I3-14 } \\
G_{U}=\mathrm{I} \cdot 68-\mathrm{I} \cdot 77 & \mathrm{I} 963 \text { October I I-12 }
\end{array}
$$

while in the region $\lambda \lambda 4_{4200-5200 \AA:}$

$$
\begin{array}{ll}
G_{B}=0.32-0.43 & 1962 \\
G_{B}=0.24 & 1960
\end{array}
$$

The spectral observations of the methan bands intensity showed that the difference in the heights of the upper cloud boundary for the dark and bright zones of Jupiter is no more than $2-4 \mathrm{~km}$. It is possible that the boundary of the dark belts is somewhat lower than of bright zones. The height of the upper boundary of the Red Spot also does not distinguish from the surrounding cloud surface.

The contrast changes of the Red Spot relatively of the surrounding surface in the South Tropical Zone were measured at the different positions of the Spot on disk. According to the observations in 1962 , the contrast of the Red Spot was $0.06-0.07$ in red, $0.30-0.32$ in blue and $0.35^{-0.40}$ in violet. The contrast decreases negligibly towards the limb. The calculations of the changes of the contrast of the Spot were carried out for two hypotheses: $(a)$ The Red Spot is a solid body with the smooth surface above that there is a layer of the atmosphere with a Rayleigh scattering having the definite optical thickness and $(b)$ The Red Spot is the cloud feature possibly connected with a rising current of gases, having the infinite optical thickness and marked true absorption.

The results of the observations are in a good agreement with the calculations only for the second hypothesis. The ratio of the coefficients of true absorption and scattering in the Red Spot is the following:

$\begin{array}{cc}\lambda & \frac{\alpha}{\sigma} \\ 6250 \AA & <0.04 \\ 5300 \AA & 0.08 \\ 4200 \AA & 0.14\end{array}$


The reflectivity of the Red Spot differs very little from that of the dark belts. The colour of the Spot is apparently of the same nature that the colour of other features of the Jupiter's cloud layer and is connected with the thermochemical changes in the cloud particles. For the solution of the question on the nature of the Red Spot it is necessary to determine its temperature. The radiometric observations taken on this purpose are so far powerless determining a temperature only of some effective layer of the overcloud atmosphere. Therefore it is very important to obtain a spectrum of the Red Spot with the high resolution and to study its temperature pecularities by the examination of the intensity distribution in the rotationvibration absorption bands.

\section{REFERENCES}

I. Kuiper, G. P., Ed. The Atmospheres of the Earth and Planets, 2nd ed., University of Chicago Press, 1952.

2. Teifel, V. G. Izv. Kom. fiz. Planet, no. I, 93-104, 1959.

3. Ambartsumian, V. A. Theoreticheskaja Astrofizika. Gostechizdat, Moskva, I952.

4. Murray, B. C., Wildey, R. L. Sky and Telesc., 27, 17, 1963.

5. Van de Hulst, H. C. in The Atmospheres of the Earth and Planets. University of Chicago Press, I952.

\section{The infra-red spectrum of fupiter obtained by Stratoscope II}

\section{R. E. Danielson}

The second flight of Stratoscope II was flown during the night of November 26-27, 1963 . During the flight, the infra-red spectrum of Jupiter was traced from $0.8 \mu$ to $3 \cdot 0 \mu$ at an altitude of 84000 feet. The entrance slit of the spectrometer was centered on Jupiter's disk and subtented an angular area of about 8.4 by 28 seconds of arc. Fig. 3 shows the observed spectrum of Jupiter obtained by detector $A$, one of two detectors operated simultaneously along the dispersed spectrum. The spectrometer sensitivity was determined by comparing the observed

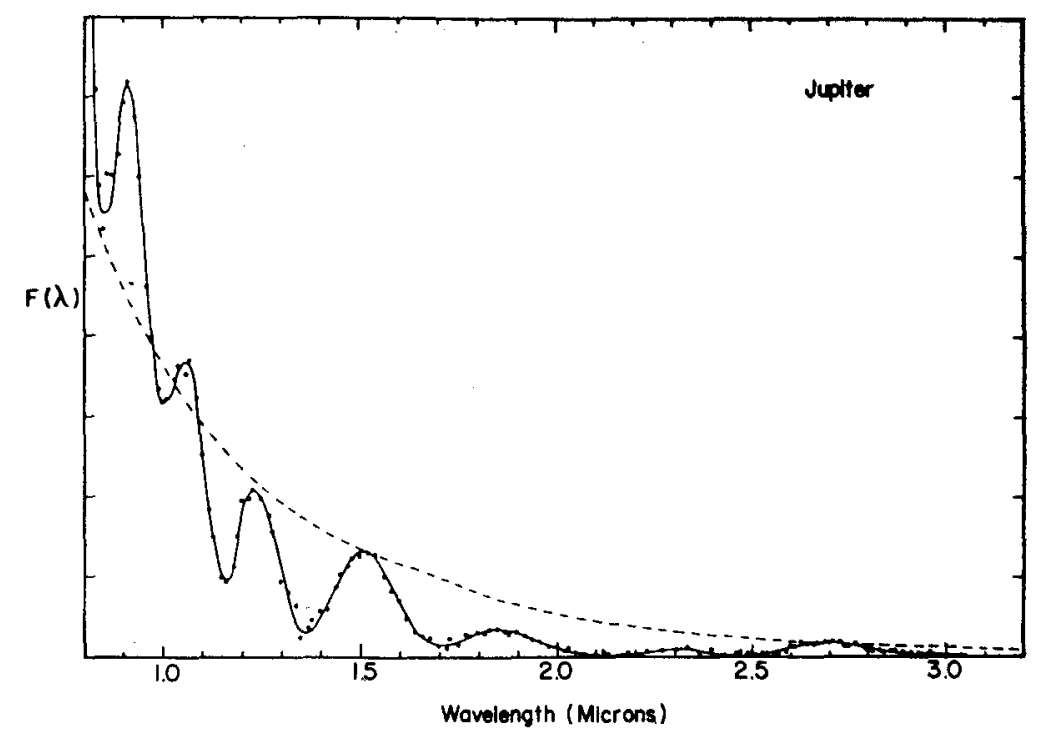

Fig. 3. The intensity of the reflected solar radiation from Jupiter (per unit wavelength interval). The dashed curve is the solar spectrum. 


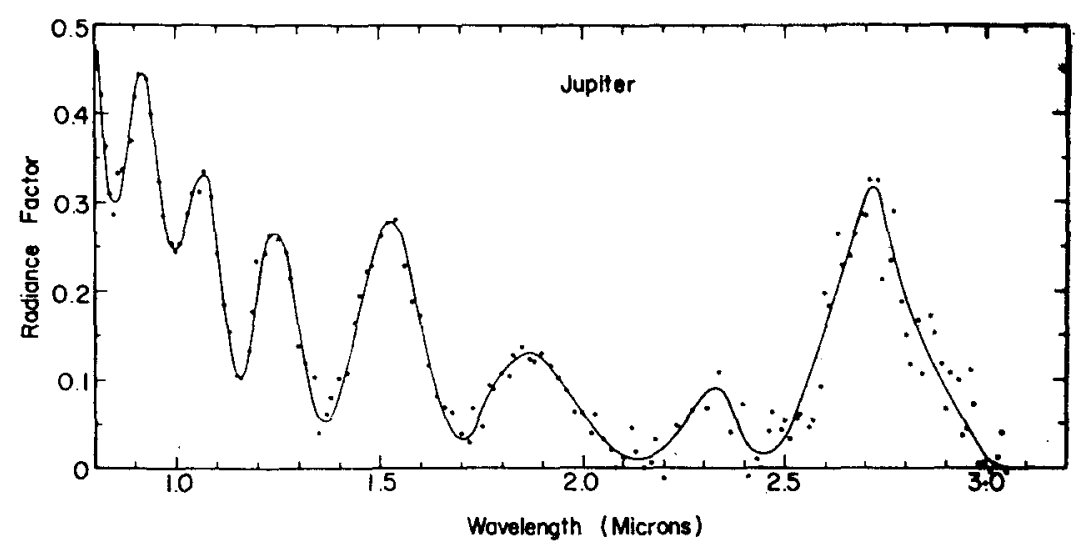

Fig. 4. The radiance factor of Jupiter in the infra-red.

spectrum of Sirius with the predicted spectrum (Woolf, Schwarzschild and Rose, I965). The only terrestrial feature detected in the spectrum of Sirius was a slight depression at $2 \cdot 7 \mu$ due to atmospheric $\mathrm{CO}_{2}$. The wavelength calibration was established by scanning a didymium source during the flight.

Fig. 4 shows the radiance factor of Jupiter (the observed brightness of a white diffuse screen at Jupiter's distance which is normal to the Sun's rays). 'The absolute accuracy is uncertain by at least 20 per cent. The bands at $0 \cdot 85 \mu, 0 \cdot 99 \mu, \mathrm{I} \cdot 16 \mu, \mathrm{I} \cdot 37 \mu$ and $\mathrm{I} \cdot 7 \mu$ all appear to be due to $\mathrm{CH}_{4}$. The fundamental band of $\mathrm{NH}_{3}$ at $3300 \mathrm{~cm}^{-1}$ causes the large absorption at 3.0 $\mu$.

The feature of most interest in the spectrum is the deep, broad absorption centered at about $2 \cdot 25 \mu$. It has two likely causes:

(I) The pressure induced band of $\mathrm{H}_{2}$ at $2 \cdot 4 \mu$ and

(2) The combination bands of $\mathrm{CH}_{4}$ at $2 \cdot 20 \mu, 2 \cdot 32 \mu 2 \cdot 37 \mu$ and $2 \cdot 42 \mu$.

Laboratory measurements of the $\mathrm{H}_{2}$ band (Chisholm and Welsh, 1954) show that the $\mathrm{H}_{2}$ band extends from about $\mathrm{I} \cdot 8 \mu$ to $2 \cdot 7 \mu$ in approximate agreement with the observed feature. Furthermore, of the order of $10 \mathrm{~km}-\mathrm{atm}^{2}$ of $\mathrm{H}_{2}$ will produce the observed amount of absorption. Since the scale height in Jupiter's atmosphere is about $20 \mathrm{~km}$, the required partial pressure of $\mathrm{H}_{2}$ at the effective reflecting level is of the order of 0.7 atmosphere. Such a partial pressure is consistent with recent estimates of the hydrogen abundance on Jupiter.

One can therefore conclude that the pressure induced dipole band of $\mathrm{H}_{2}$ at $2.4 \mu$ is at least partially responsible for the large feature. The contribution of the methane bands to this feature is uncertain because of the lack of appropriate laboratory data.

Project Stratoscope of Princeton University is sponsored by NSF, ONR and NASA.

\section{REFERENCES}

Chisholm, D. A., Welsh, H. L. Can. F. Phys., 32, 291, 1954.

Woolf, N. J., Schwarzschild, M., Rose, W. K. Astrophys. F. In press.

\section{Infra-red spectra of Jupiter and Saturn \\ W. Sinton}

L. Fredrick has a number of spectra of Jupiter and Saturn with a mica-window image intensifying tube between 9800 and I I $200 \AA$. The dispersion was $46 \AA / \mathrm{mm}$. The observations were made with the Lowell 24 -inch Morgan reflector. 
Laboratory spectra of methane and ammonia were made for comparison with the planetary spectra. The intensity of the methane bands were roughly matched with a 22-meter path of methane at 5 atmosphere pressure. The ammonia band intensity was matched with a 22-meter path and a $2 / 3$ atmosphere pressure.

On spectra of the disk of Jupiter no lines were found which could not be explained by either methane, ammonia, solar or terrestrial lines. On Saturn only methane, solar and terrestrial lines could be found. A broad weak band was found in the rings of Saturn at to $800 \AA$.

Spectra of Io were taken when the satellite was I second of arc from the limb just before it was occulted by Jupiter. On this night the seeing was very excellent. No lines of methane or ammonia were found, showing that these gases are not present in any extended atmosphere.

\section{The thermal opacity in the major planets}

\section{G. Münch}

Radiometric and visual observations indicate the presence of an infra-red opacity in the Jovian atmosphere, so far unidentified. Recent laboratory work suggests the importance of estimating the absorption coefficient of molecular hydrogen arising from the distortion of the molecules during collision and from quadrupolar induction. The rotational and translational transitions of this pressure induced absorption appear to play an important role in the energy balance of the major planets. As a preliminary analysis, a gray model in hydrostatic and radiative equilibrium has been constructed by Lawrence Trafton from the monochromatic absorption coefficients of $\mathrm{H}_{2}$. A Planck mean was used taking into account only the density dependence of the absorption and an effective temperature of $110^{\circ} \mathrm{K}$ was adopted. The results of the integrations show that a path-length of $30 \mathrm{~km}$-atm of $\mathrm{H}_{2}$ has sufficient opacity to produce a substantial greenhouse effect and bring the local temperature to $147^{\circ} \mathrm{K}$. The radiative temperature gradient becomes unstable against convection at an optical depth in the thermal spectrum of $2 \cdot 8$, where the temperature is $140^{\circ} \mathrm{K}$. On this basis it appears that it is possible to construct a model for Jupiter's atmosphere in hydrostatic equilibrium and with no other source of energy than solar radiation.

\section{I0. Color and molecular absorption over the disks of Jupiter and Saturn}

\section{G. Münch, R. L. Younkin}

The distribution of color and molecular absorption over the disks of Jupiter and Saturn has been studied photo-electrically with a scanning spectrometer attached to the 6o-inch Mount Wilson telescope between 0.33 and $I \cdot I$ microns. The limb darkening observed in the strong $\mathrm{CH}_{4}$ bands at 0.73 and 0.89 microns shows striking differences from those obtained in the neighboring continuum. At $\lambda 0.88$ microns we observe in Jupiter a sharp and narrow polar limb brightening, indicating the existence of a very high level cloud, possibly formed by frozen $\mathrm{CH}_{4}$. Photographs taken through an interference filter center at 0.73 micron confirm the existence of bright polar caps in Jupiter. Additional observations of the major planets at large dispersion are being done photo-electrically with the Ioo-inch coudé scanner by G. Münch. It has been found that the various bands of $\mathrm{NH}_{3}$ and $\mathrm{CH}_{4}$ in Jupiter do not show the same variation in intensity over the disk or toward the limb. It appears that all lines arise by diffuse reflection and that the pressure dependence of the ratio between continuous scattering and band or line absorption coefficients is not the same for all bands. The possibility of studying the variation of the pressure with height through observations of bands or lines of different intensity is thus suggested. A special search for $\mathrm{NH}_{3}$ features in Saturn has lead to negative results and earlier reports on the presence of $\mathrm{NH}_{3}$ in Saturn must be considered resulting from misidentification of $\mathrm{CH}_{4}$ lines in the 0.79 micron region with $\mathrm{NH}_{3}$ lines. 


\section{I1. On radiative transfer in the atmosphere of Fupiter}

\section{Sagan}

This work has been performed jointly with Dr Andrew T. Young, of Harvard College Observatory, and Dr Philip L. Hanst, of the AVCO Corporation, Wilmington, Massachusetts. Spectra have been taken in a long-path multiple-traversal cell of the quantities of methane and ammonia deduced for the Jovian atmosphere from near infra-red spectra. The laboratory spectra were taken at a variety of total pressures and $\mathrm{NH}_{3}$ and $\mathrm{CH}_{4}$ mixing ratios. Since the opacity of ammonia in the 8-1 $3 \mu$ region is very high, the temperatures deduced by observations of Jupiter through the $8-13 \mu$ interval must apply to a region in the Jovian atmosphere far above the visible clouds. The invisibility of the Great Red Spot in the bolometric observations of Murray, Wildey, and Westphal confirms this interpretation. If the atmosphere above the clouds is in convective equilibrium, the temperature at the cloudtops may be much larger than that deduced from observations at $8-13 \mu$. The infra-red integrated opacities of methane and ammonia, together with the opacity due to quadrupole transitions in hydrogen, computed by Trafton, are very high. Even if the atmosphere above the clouds is in radiative equilibrium, the temperature at the cloudtops must be greater than that deduced in the past. If the atmosphere above the clouds is in convective equilibrium, the temperature at the cloudtops will be so high that their identification as ammonia cirrus must be seriously questioned. Lower vapor pressure materials must then be invoked. On cosmic abundance grounds, the most likely of these is water.

\section{On the temperature and radiative balance of 'Jupiter's atmosphere}

\section{D. Kaplan}

Öpik's (I) argument for an internal heat source for Jupiter depends mainly on the opacity from 8 to $14 \mu$ being as high as or higher than elsewhere in the spectrum, as this is the spectral region for which brightness temperatures of about $130^{\circ} \mathrm{K}$ have been obtained. This is, in fact, probably the most transparent part of the spectrum of the Jovian atmosphere. The high opacity observed for laboratory $\mathrm{NH}_{3}$ out to $\mathrm{I}_{4} \mu$ is due to the population, at room temperature, of many states with high energy levels. However, of the hundreds of lines between $12 \cdot 35 \mu$ and I $4 \mu$ or higher, only 19 have lower-state energies corresponding to wave-numbers less than $900 \mathrm{~cm}^{-1}$, and none less than about $600 \mathrm{~cm}^{-1}$. The intensities of these lines would be reduced, at Jovian temperatures, by an order of magnitude, and all the others by two orders of magnitude or more. Below $12.35 \mu$, there are many lines of small lower-state energies, but they tend to clump and provide high opacity over only about one-fourth of the central portion of the band. Applying the above temperature corrections to spectra shown in the previous paper by Sagan, it is seen that the absorption, by $7 \mathrm{~m}$-atm. of $\mathrm{NH}_{3}$ in the Jovian atmosphere, would indeed be small at wavelengths greater than $12 \cdot 35 \mu$. Since the blackbody radiation at the low temperatures is heavily weighted toward much higher wavelengths, there appears to be no problem with the heat balance if the atmosphere is opaque at longer wavelengths, as Münch has shown in the previous paper to be the likely result of pressure-induced $\mathrm{H}_{2}$ absorption.

The wings of the induced dipole lines of $\mathrm{H}_{2}$ extend below $\mathrm{I} 4 \mu$, and the amount of cloud radiation that is allowed to escape to space depends very strongly on the pressure of the cloud top. If the cloud-top pressure is less than three atmospheres, as seems likely both from the $\mathrm{CH}_{4}$ line-width measurements by Spinrad and Trafton (z) and from $\mathrm{H}_{2}$ quadrupole absorption measurements together with estimates of mean molecular weight from occultation measurements, the opacity of the Jovian atmosphere is less than one-half from 9 to $13 \mu$. The cloud-top temperature, as derived from the radiometric measurements, would then be between $140^{\circ} \mathrm{K}$ 
and $150^{\circ} \mathrm{K}$. The small atmospheric opacity is supported by the absence of appreciable limb darkening in the measurements of Murray, Wildey and Westphal (3). (Münch indicated in discussion that the amount of limb-darkening at large air-masses is still questionable).

\section{REFEREN CES}

I. Ópik, E. J. Icarus, $1,200,1962$.

2. Spinrad, H., Trafton, L. M. Icarus, 2, 19, 1963.

3. Murray, B. C., Wildey, R. L., Westphal, J. A. Astrophys. F., 139, 986, x964.

\section{A search for Jovian $H$-alpha auroral activity}

\section{(Abstract of remarks from Harlan $\mathscr{\jmath}$. Smith)}

Radio observations, particularly at decametric wavelengths, have shown the existence of strong Jovian radiation belts. Dumping of such particles into the Jovian atmosphere must occur from time to time, if not continuously, presumably producing a Jovian analogue to terrestrial auroras; optical detection of such auroras would permit direct location of Jupiter's magnetic poles.

Search for Jovian auroral activity was undertaken at Yale originally in the H-alpha line among other reasons because the Balmer lines are relatively conspicuous in many terrestrial auroras and because hydrogen is presumably an abundant constituent of Jupiter's atmosphere. A photo-electric comparison spectrophotometer largely designed and constructed by James Rodman (I) was used with the Yale Observatory 20-inch reflector to compare ${ }_{5} \AA$ centered on $\mathrm{H}$-alpha with a pair of flanking roo $\AA$ comparison bands having edges separated $40 \AA$ from the edges of the H-alpha band. Separate EMI $955^{8}$ photomultipliers simultaneously registered the $\mathrm{H}$-alpha and the combined comparison beams, reading into pulse-counting electronics, normally with 2-minute integration times.

Observations were made by setting the edge of a 6 second square slit barely onto the limb of Jupiter at a well-defined position angle on the apparent disk, with subsequent readings advancing by $22^{\circ} \cdot 5$ around the limb. In this way the maximum light path through Jupiter's atmosphere was continually sampled over the complete range of latitudes and, with the rotation of Jupiter, over all longitudes. Calibrated reduced ratios of $\mathrm{H}$-alpha intensity to the adjacent continuum were mapped by computer onto a Jovian coordinate system.

More than 3000 observations over the period August-December 1962 (Smith, 2, 3) gave $\mathrm{H}$-alpha intensity maps showing no significant average systematic enhancement of $\mathrm{H}$-alpha as great as .003 over any latitude belt or any small circle that might reasonably be interpreted as an auroral ring surrounding a magnetic pole. That is, this program detected no continuous auroral enhancement of the $\mathrm{H}$-alpha light reflected from the Jovian atmosphere as great as an average of about 3 kilorayleighs.

Factors which may contribute to this failure to detect Jovian auroras to this reasonably high level of sensitivity include the low state of solar activity in late 1962 , the possibility that auroras may physically be a night (back-side) phenomenon, and (as suggested by Spitzer) the hydrogen present in Jupiter's atmosphere and ionosphere may be almost entirely molecular.

\section{REFERENCES}

r. Rodman, J. P. App. Opt., 2, 165, 1963.

2. Smith, Harlan J., Rodman, J. P., Sloan, Wm. A. Astr. Y., 68, 79 (abstr.), 1963.

3. Smith, Harlan, J. Proceedings NASA Conference on Fupiter. In press, 1964. 
DISCUSSION

Münch et Smith: La valeur de 3 kilorayleighs justifie l'échec à l'égard de la détection d'aurores probablement à cause de la présence d'hydrogène moléculaire ionisé sur Jupiter.

Menzel: Est-ce qu'on observe des aurores sur Jupiter lors d'une éruption solaire?

H. F. Smith: On n'a rien observé.

\section{A further search for $H \alpha$ aurorae on $F u p i t e r$}

$$
\text { J. V. felley }
$$

Continuing our search (I) for $\mathrm{H} \alpha$ emission aurorae from Jupiter, which it is felt might exist in association with the decametre radio storms (at least if we assume these originate down at ionospheric levels), experiments were carried out at the Observatories, Cambridge, during the Opposition of 1962 , and at the University Observatory, the Department of Astrophysics, Oxford, during the Opposition of 1963 .

\section{Cambridge (1962). D. W. Dewhirst, R. F. Griffin, F. V. Jelley, and A. D. Petford}

(I) Equipment. A I5-inch refractor fed from a siderostat was used in conjunction with a two-channel photo-electric photometer, the light being switched alternately, at I cycle per second, through two interference filters, and detected in a single cooled phototube with a trialkali cathode, and used in conjunction with a photon pulse counting system.

The signal channel filter had a bandwidth of $12 \AA$ and could be 'tuned' from $H \alpha$, at $\lambda{ }_{65} 63 \AA$, to $\lambda 6547 \AA$, while the reference channel filter was fixed at $\lambda 6440 \AA$, with a passband of $20 \AA$.

Since in 1962 the orientation of the planet's magnetic axis had barely been established, the observations with this instrument were made through an input slit of width $0.043 \mathrm{~mm}$ and length $1 \cdot 2 \mathrm{~mm}$ placed centrally on the meridian of the planet's primary image, whose equatorial diameter was I.04 mm. The observations were made between September I3 and October 9 and no attempt was made to correlate them with periods of known radio-storm activity. If $\gamma$ is the ratio of the light in the $\mathrm{H} \alpha$ channel to that in the reference channel, with the signal channel 'on tune', to the same quantity with the signal channel 'off tune', it was found that when averaged over the whole System III longitude range, $\gamma=0.8870 \pm 0.0012$. The difference between this quantity and unity is consistent with the depth and width of the reflected solar $\mathrm{H} \alpha$ absorption line, taking into account the width of the signal-channel filter. We assumed that any auroral activity would appear approximately in the same longitude range as the storm activities, namely $\lambda$ (System III, $1957^{\circ}$ ) $=227^{\circ}$, with an effective $\Delta \lambda$ of $\pm 22^{\circ}$, which figures were the mean of observations by several radio groups. In this longitude range it was found that $\gamma=0.8894 \pm 0.0018$. From these figures for $\gamma$, we deduce that any excess $\mathrm{H} \alpha$ emission within the main lobe of the decametre radiation can only have an intensity of $(0.27 \pm 0.25)$ per cent of the reflected-light continuum within the narrow strip accepted by the input slit, and covering the full range of latitude on the planet.

These experiments were complementary to others carried out previously (2) (3) (4), all of which have also failed to detect an $\mathrm{H}_{\alpha}$ aurora. In contrast to the works (3) and (4), our limiting sensitivity was lowered by the decision to embrace all latitudes on the planet simultaneously, thus diluting any $\mathrm{H} \alpha$ enhancements restricted to auroral zones. Our light collection and resolution were, however, comparable, to that used in (3) and (4), with the grating instrument described elsewhere (5).

(2) An entirely different type of experiment was then attempted, in November 1963 , using the three-channel photo-electric spectrograph at the coude focus of the 36 -inch reflector (6). 
It was considered worth while to investigate the possibility that the van Allen belt particles associated with the decimetre radiation (7) might excite $\mathrm{H} \alpha$ in the outer exosphere of the planet, where the relatively low particle flux and low gas densities might produce only a weak aurora, but one which might be observable in 'off-limb' observations, for which the background radiation, in the absence of the planet's direct light, was found to be $\sim$ I/600 of that on the disk of the planet. In this experiment we were seeking $\mathrm{H} \alpha$ enhancement off the equatorial rather than the polar limbs.

A circular aperture of diameter $0.97 \mathrm{~mm}$ was placed at the position of the entrance slit of the spectrograph, and the $\mathrm{I} \cdot \mathrm{O}_{4} \mathrm{~mm}$ diameter primary image of the planet was guiding so that its tangent was 0.3 of the planet's radius from the tangent to this input aperture. With this arrangement, at a dispersion of $6.5 \AA / \mathrm{mm}$ at $\mathrm{H} \alpha$, the resolution was $6 . \circ \AA$, while the two reference channels were each of width $20 \AA$. The results for the ratio $\left(\times 10^{3}\right)$ of the light in the signal to that in the reference channels are listed below.

\begin{tabular}{|c|c|c|c|c|c|}
\hline Off-limb posi & ion & $\mathbf{N}$ & $\mathbf{f}$ & $\mathbf{S}$ & p \\
\hline Nov. 19 & & 996 & 1003 & 996 & 1004 \\
\hline Nov. 22 & & 978 & 994 & 1017 & IOI I \\
\hline Combined & Nov. 19 & polar & 9963 & equatorial & 10037 \\
\hline Combined & Nov. 22 & & 9975 & & 10025 \\
\hline & & & 9969 & & $1003 x$ \\
\hline
\end{tabular}

It is not possible to quote errors since these were non-statistical, but it is clear that there is no enhancement over the equator, or over the poles, which is significant at the existing sensitivity limits.

\section{Oxford (1963). F. V. Felley and A. D. Petford}

In the belief that an $\mathrm{H} \alpha$ auroral emission from the planet would be expected to have a linewidth narrow compared with the reflected $\mathrm{H} \alpha$ solar absorption profile, it was decided to have a further attempt, to search for any 'fflling up' of the solar $\mathrm{H} \alpha$ line, using a much higher dispersion. With the high resolution solar spectrograph at the observatory, photo-electric scans were made over a $7 \AA$ band centred on $\mathrm{H} \alpha$, using again a cooled phototube and pulse-counting. The diameter of the planet's image was $4: 3 \mathrm{~mm}$, and a circular entrance aperture of diameter $\mathrm{I} \cdot 26 \mathrm{~mm}$ was automatically guided to straddle the limb of the planet. With an effective entrance-slit. width of $0.52 \mathrm{~mm}$, and an exit slit of width $0.61 \mathrm{~mm}$, a resolution of $0.4 \mathrm{I} \AA$ was obtained at a dispersion of $0.29 \AA / \mathrm{mm}$, with a 600 line $/ \mathrm{mm}$ Babcock grating operating at fourth order. With the aperture placed centrally on the disk line profiles were taken from ro scans, and were found to fit closely the profile of the solar $\mathrm{H} \alpha$ line as published in the Utrecht Atlas.

Six scans were then made over \pm I $\AA$ from the $H \alpha$ wavelength corrected for orbital Doppler shift, from light accepted from the polar limbs. In this experiment, owing to limb-darkening, it was found that the emission over this band was only ( Io \pm 3 ) per cent of that from the centre of the disk, at a wavelength of $-3.3 \AA$ from the line-centre wavelength (i.e. close to the continuum level). There was no detectable enhancement within this $2 \AA$ band.

In conclusion, in view of Öpik's view (8) that $\sim 97$ per cent of the atmospheric content of Jupiter is $\mathrm{He}$, a limited number of scans were carried out on the He $\mathrm{r}$ lines at $6678 \AA$, and $5876 \AA$ again without any positive results.

We would like to suggest finally that an experiment should be done in which short-exposure spectrograms are taken on the polar regions with an instrument of high light-grasp at high resolution, possibly with the aid of an intensifier, and that these exposures should be triggered directly from adjacent radio-storm detecting equipment. 


\title{
REFERENCES
}

I. Jelley, J. V., Petford, A. D. Observatory, 8r, I04, I96r.

2. Carr, T. D., Smith, A. G., Bollhagen, H., Six, N. F., Chatterton, N. E. Astrophys. 7., 134, 105, 1961.

3. Douglas, J. N., Smith, H. J. Astr. F., 68, 163, 1963.

4. Smith, H. J., Rodman, J. P., Sloan, W. A. Astr. F., 68, 79, I963.

5. Rodman, J. P. App. Opt., 2, 165, 1963.

6. Griffin, R. F., Redman, R. O. Mon. Not. R. astr. Soc., 120, 287, 1961.

7. Roberts, M. S., Huguenin, G. R. IIth International Colloquium, 'The Physics of the Planets'. University of Liège, 24, 569, I962.

8. Öpik, E. J. Icarus, I, 200, 1962.

\section{Session scientifique $\mathbf{I}$}

NATURE ET STRUCTURE DU SOL LUNAIRE

\section{Radiometric and photometric mapping of the Moon through a lunation}

\author{
R. W. Shortill, f. M. Saari
}

\section{Measurements}

Mapping of the illuminated lunar disk has been accomplished simultaneously at two wavelengths for more than 20 phases of the Moon. Isothermal and isophotic contours are produced which can be related to visible surface features. The specific goals of the program are:

(I) To investigate the radiometric properties of the lunar surface.

(2) To provide more photometric information taken photo-electrically.

(3) To investigate the relationship between albedo and surface temperature.

(4) To follow the temperature curves of specific areas of interest such as rayed craters.

(5) To search for areas which are thermally anomalous under illumination. A photomultiplier was used for measuring the reflected light, its peak response chosen to be $445 \circ \AA$ corresponding to that used by Rougier in his measurements of the light curve for the illuminated disk as a function of phase. The photometric data from each complete scanning can be integrated and normalized to his curve. A mercury doped germanium photodetector, cooled to liquid hydrogen temperature, was used with a Io-I2 micron filter and calibrated with black bodies at known temperatures. Corrections for atmospheric transmission can be made using ground and balloon-sonde meteorological data.

Both detectors had a spatial resolution of $8^{\prime \prime}$ of arc and were placed at the Newtonian focus of the Mount Wilson 6o-inch telescope. The Moon was scanned at $530^{\prime \prime}$ of arc per second of time with a separation between scan lines equal to the aperture diameter; therefore the entire lunar disk was covered, a full Moon requiring about 240 scan lines.

It took a half hour or less to perform a scan program, depending on the phase of the Moon and the orientation of the scanning device. The signals were recorded in analog form on magnetic tape for subsequent data reduction by an IBM 7094 computer, giving position versus brightness temperature and light intensity to a scale such that $\frac{3}{8}$ inch is equal to $8^{\prime \prime}$ of arc. Four or five pairs of contours have been reduced. It will require about a year to process and construct all the isothermal and isophotic charts.

\section{Thermal anomalies}

While the above measurements were being made, it was possible to make some infra-red measurements on the dark side of the Moon with minor modifications to the equipment. Thermal anomalies were found on the rayed craters Proclus and Strabo, in agreement with 
previous work during eclipses by the Boeing, Flagstaff, and Harvard groups, and on the dark side by the Cal Tech Group. In addition, are found positive anomalies not associated with rayed craters:

(I) About $140 \mathrm{~km}$, east of Plinius;

(2) East of Arago in the sea of Tranquility;

(3) Over the Hyginus Rille.

There appear to be negative anomalies on the illuminated disk of the Moon which are not obviously the result of albedo or local geometry. One, amounting to $5^{\circ} \mathrm{K}$, has been observed on the edge of Mare Imbrium situated about one-third the distance from Copernicus to Aristarchus within several clays of local sunset; at full Moon it seems to disappear. The temperature history chiring a lunation of this region (and others) will be studied closely as more of the data are reduced.

\section{Surface roughness and thermal anomalies}

The thermal anomalies have been interpreted as being due to a thinner dust layer. An alternative interpretation in terms of enchanced roughness in the vicinity of rayed craters is being studied. So far a rather simplified model consisting of a flat surface interspersed with cavities has been considered; under illumination, with the albedo assumed to be zero, the entire surface comes to a uniform temperature. During an eclipse, when the solar radiation is suddenly removed, the cavities cannot cool as rapidly as the flat areas. An infra-red detector pointed to the area will see a composite surface of warmer and cooler areas, resulting in an apparent brightness temperature higher than the environs. Topographical profiles calculated for a range of temperature differences between rayed craters and their environs using V-shaped trenches for the cavities appear to give a reasonable scale of roughness for these features. The enchanced radar returns observed from several rayed craters are compatible with this theory.

The additional parameters offered by this theory can be used to resolve the discrepancy that has appeared to exist between eclipse and lunation cooling of the general lunar surface. The calculations revealed a smoother surface than necessary to explain the rayed crater anomalies. In addition, the scale of this roughness may well be on a smaller scale and could result from the continuing bombardment of the lunar surface by micrometeorites.

Work on most sophisticated models for this theory is underway.

\section{Lunar research at Harvard College Observatory}

\section{H. C. Ingrao, D. H. Menzel}

We have discussed the principle of operation of the radiation pyrometer for lunar work developed at Harvard College Observatory ('Radiation pyrometer for lunar observations'. Scientific Report no. 4, NASA Grant NsG 64-60). We have stressed the problem of locating the projection of the resolution element on the lunar surface when working with high spatial resolution. The pyrometer has two channels, infra-red and visual-photographic, operated by a mirror chopper. The chopping frequency can be continuously varied from io cycles per second to 70 cycles per second with the choice of frequency depending upon the scanning rate.

The pyrometer can take different detectors and electronics, the change takes only seconds. The detector we use at present is an immersed germanium thermistor bolometer, $0.1 \mathrm{~mm} \times$ $0.1 \mathrm{~mm}$ in size. The noise level with a 4 second post-detection time constant is $5 \times 10^{-11}$ watts peak to peak. We have the choice of two band pass filters, $8 \mu-14 \mu$ or $8 \cdot 3 \mu-9^{\cdot} 2 \mu$.

The pyrometer has well calibrated reference and calibration black bodies. The output is recorded in analog form, but an analog digital converter is under construction. 
The visual-photographic channel subtends a field of view of $7^{\circ} 0^{\prime} \times 4 \cdot 5^{\prime}$ and has in the center a cross hair that indicates the equivalent position of the detector. The accuracy in locating the resolution element on the Moon could be of the order of $\pm \mathbf{I}^{\prime \prime} 5^{\prime \prime}$.

The infra-red signal, timing marks (WWV) and picture frame marks are simultaneously recorded on the same three channel paper chart. The conversation of the observer and the operator of the electronics, timing marks (WWV) and event marks are recorded on magnetic tape.

At the end of 1963 and during 1964 the scannings of the Moon were secured at different observing sites.

The total lunar eclipse of 1963 December 30 was observed by Hector C. Ingrao and Andrew T. Young from the Dominion Astrophysical Observatory, Victoria (Canada), using the radiation pyrometer attached to the 72 -inch reflector at the Newtonian focus. Because weather conditions were generally poor, we reduced only the data gathered during intervals of good weather. The following table gives the results:

\begin{tabular}{|c|c|c|c|c|}
\hline Name of crater & $\begin{array}{c}\text { Approximate } \\
\text { size } \\
\text { (sec of arc) }\end{array}$ & $\begin{array}{c}\text { Observation } \\
\text { time } \\
\text { (U.T.) }\end{array}$ & \multicolumn{2}{|c|}{$\begin{array}{c}\text { Temperature anomaly } \\
\Delta T\left({ }^{\circ} \mathrm{C}\right)\end{array}$} \\
\hline Aristarchus & 20 & $8^{\mathrm{h}} 56^{\mathrm{m}} 30^{\mathrm{s}}$ & \multirow{2}{*}{\multicolumn{2}{|c|}{$\begin{array}{l}7^{\circ} \mathrm{C} \pm 5^{\circ} \mathrm{C} \text { (warmer* } \\
12^{\circ} \mathrm{C} \pm 5^{\circ} \mathrm{C} \text { (cooler*) }\end{array}$}} \\
\hline Censorinus & 3 & $8^{\mathrm{h}} 09^{\mathrm{m}} 55^{\mathrm{s}}$ & & \\
\hline Dionysius & 9.5 & $8^{\mathrm{h}} 1^{8^{\mathrm{m}}} 43^{\mathrm{s}}$ & $7^{\circ} \mathrm{C} \pm 1^{\circ} \mathrm{C}$ & $"$ \\
\hline Fracastorius A & $8 \cdot 5$ & $8^{\mathrm{h}} 25^{\mathrm{m}} 37^{\mathrm{s}}$ & $7^{\circ} \mathrm{C} \pm 22^{\circ} \mathrm{C}$ & $"$ \\
\hline Proclus & 15 & $7^{\mathrm{h}} 4^{8^{\mathrm{m}}} 30^{\mathrm{s}}$ (?) & $10^{\circ} \mathrm{C}$ & $"$ \\
\hline Pytheas & II & - & ? & \\
\hline
\end{tabular}

* than the background.

The size of the resolution element during the measurements at the Dominion Astrophysical Observatory were $8^{\prime \prime} \times 8^{\prime \prime}$.

The lunar eclipse of 1964 June $24 / 25$ was observed by Hector C. Ingrao and Andrew $T$. Young from the Radcliffe Observatory in Pretoria (Republic of South Africa), using our radiation pyrometer attached to the 74 -inch reflector at the Newtonian focus.

Before commencing the lunar measurements we allowed the detector to be scanned by Alpha Scorpii in order to determine the responsivity profile of the detector and its position with respect to the reticle. The reticle then enables us to determine the locations of the resolution element on the lunar disk.

In the early part of the night, prior to the eclipse, scans were made of Aristarchus, Censorinus, Dionysius, Proclus and Menelaus. After the beginning of the eclipse scans were made across the entire Moon in an east to west direction through the center of the disk. The scans passed north of Censorinus and south of Dionysius. From the scans we will construct cooling curves for areas of the Moon at all distances from the center of the disk.

During totality, because of the darkness of the eclipse (it was not as dark as the eclipse of I 963 December 30 ) our photographic system was unable to locate the position of the resolution element on the lunar disk; however, we took pictures of the limb at the entrance and exit of the scanning with stars in the background.

During totality we secured scans showing temperature anomalies (hotter on cooler background) in different areas and we are confident that on the basis of the few photographic data and extrapolation from the scanning mode of the telescope, we will be able to identify the position of the scans. The data is in the process of reduction.

Before, during, and after an eclipse the South African Weather Bureau launched meteorological balloons to measure the total amount of precipitable water. The lowest value was $2.5 \mathrm{~mm}$. 
An isothermal map of the Proclus region included between selenographic latitude parallels $+8^{\circ}$ and $+20^{\circ}$ and selenographic longitude circles $+38^{\circ}$ and $+60^{\circ}$ has been made. The region was scanned with the pyrometer at the Newtonian focus of the 6I-inch Weyth reflector of Harvard College Observatory when the Moon was 14.5 days old.

The results were reduced and the isotherms plotted by Harold Boeschenstein, Jr. The temperature increments between isotherms range from $\Delta T=0.7^{\circ} \mathrm{C}$ to $\Delta T=0.9^{\circ} \mathrm{C}$. The accuracy in the location of the resolution is in the order of \pm 6 seconds of arc. The isotherms suggest that the observed temperature gradients depend more on the slope and surface structure than on the visual albedo.

A mosaic photograph composed of prints made from the identification negatives taken with the pyrometer camera was made, and I040 points representing fixed power level intervals were plotted on it. The isotherms were drawn through points of equal power level (Fig. 5).

From the work which has been done so far by Hector C. Ingrao and Andrew T. Young, temperature anomalies have been observed in the following craters: Aristarchus, Censorinus, Dionysius, Fracastorius A, Lalande, Manilius, Menelaus, Proclus, Pytheas (?), Taquet.

Hector C. Ingrao reported that Andrew T. Young has written a 7094 FORTRAN computer program that traces accurately the path of a scanning line across the Moon using the data from the radiation pyrometer. The telescope may be moving at a uniform rate in either hour angle and declination, or if desired in both. The program accepts as input, data from the Ephemeris, the lunar orthogonal coordinates $(\xi, \eta)$ of one or more points along the scan, and the time at which each point is scanned. It produces, as output, the following data for specified intervals during the scan: Orthogonal coordinates $(\xi, \eta)$; the altitude of the Sun; the difference in azimuth of Earth and Sun; and the phase angle (angular separation of Earth and Sun). In each case, 'Earth' refers to the position of the observer, not the center of the Earth. The error in the computed quantities corresponds to less than I second of arc in the sky, or -oor lunar radius; the accuracy of the results is in practice governed by the accuracy of the input coordinates and times.

\section{Lunar radar measurements at $70 \mathrm{~cm}$}

\section{G. H. Pettengill}

Lunar radar measurements at $70 \mathrm{~cm}$ using the $300 \mathrm{~m}$ reflector of Cornell University in Puerto Rico have been initiated. In these observations the technique of range-Doppler mapping has been employed to achieve a lunar surface resolution of about $20 \mathrm{~km}$ by $40 \mathrm{~km}$. So far, regions containing the craters Tycho, Kepler, Copernicus, Langrenus, and Theophilus have been examined. In all cases anomalously high surface reflectivity has been observed which corresponds well in position with the visual feature. Moreover, many smaller craters of dimensions substantially less than the resolution cell have also been observed. The technique appears to be particularly useful in locating regions which are unusually rough at the scale of the radio wavelength used. Polarization measurements imply that the scattering mechanism in these regions is predominantly due to a rough surface rather than merely a series of highly inclined smooth surfaces.

\section{DISCUSSION}

Shoemaker: Which is the orientation of the map?

Gold: L'orientation des pentes explique les différences des signaux reçus.

Pettengill: Not only the inclination of the 'pentes', but scattering, is due to the roughness of the surface at the scale of wavelength. The question of the 'pentes' goes along with function of libration. 


\section{Moon luminescence}

\section{f. E. Geake, C. F. Derham, f. C. G. Walker}

There is some evidence that the Moon is luminescent, and we have been trying to simulate this in the laboratory. We have bombarded dust samples with UV and with protons (usually about $40 \mathrm{keV}$ ), and have recorded the spectrum of any luminescence with a photo-electric spectrophotometer. A range of different types of stony meteorites has been investigated under proton excitation; they mostly luminesce negligibly or weakly, but the enstatite achondrites alone luminesce strongly, with an efficiency approaching I per cent and a spectrum consisting of a strong red peak at $6700 \AA$ and a weaker blue peak at $4000 \AA$. We find that it is the enstatite component which luminesces, but that it is present in two states which luminesce predominantly red and blue respectively. The colour appears the same for a wide range of proton, electron and X-ray excitation; however, under UV excitation the emission is white and very feeble.

The meteorites studied under proton excitation seem to be in three efficiency groups, in narrow ranges around $I, I / 20$ and $I / 200$ per cent with none in between.

It seems more likely that the observed luminescence of the Moon is due to potentially luminescent (but radiation damaged) regions of the lunar surface being freshly exposed by meteoritic or volcanic disturbances, than that it is due to the meteoritic material itself. Enstatite has been suggested earlier as a possible lunar surface material.

\section{DISCUSSION}

E. Opik: Is luminescence or fluorescence of the surface of the Moon the result of the permanent solar wind only?

Z. Kopal: Luminescence in several spectral ranges have to be related with solar flares. The total brightness of full Moon is correlated with solar activity. The organization of a Committee between Commissions $I 6$ and 10 for systematic study of lunar luminescence and solar activity should be particularly efficient.

T. Gold: Particles bombardment makes a luminescence of $10^{-6}$. Above views are insoutenable because luminescence will occur also in the dark part of the surface of the Moon. A UV source of energy has to be involved.

\section{Effect of solar wind on optical properties of the lunar surface}

\section{T. Gold}

(No abstract received)

\section{Interprétation des propriétés polarimètriques de la lumière diffusée par le sol lunaire}

\section{A. Dollfus}

Les études polarimétriques entreprises jadis par B. Lyot, puis développées par l'auteur, sur la Lune et des échantillons terrestres avaient montré que la couche superficielle recouvrant le sol lunaire est constituée par une poudre formée de petits grains enchevétrés de facon complexe, et constitués par un matériau très absorbant, c'est-à-dire complètement opaque sous l'épaisseur de quelques longueurs d'ondes.

De nouveaux échantillons minéraux broyés en fines poudres ont été mesurés à l'Observatoire de Meudon; ils ont été choisis en raison des différentes hypothèses émises récemment sur la composition du sol lunaire. 
Des tektites d'Indochine, des échantillons du revètement intérieur bréchiforme du Meteor Crater de l'Arizona, des Obsidiennes basiques ou acides, des Ignimbrites donnent des poudres beaucoup trop claires, avec une polarisation trop faible et presque dépourvue de la branche initiale négative qui caractérise la surface lunaire.

Des météorites pierreuses achondrites pulvérisées se comportent de la même façon, ainsi que de nombreux échantillons de chondrites. Une seule météorite chondritique pulvérisée très sombre et très chargée en olivine (Karoonda) a donné une polarisation de la lumière se rapprochant de celle de la Lune.

Des cendres volcaniques sombres ou des laves volcaniques pulvérisées donnent des courbes de polarisation très semblables à celles de la Lune; des mélanges convenables de cendres de différents pouvoirs réflecteurs reproduisent convenablement les propriétés polarimétriques du sol lunaire en lumière jaune (comme Lyot l'avait déja indiqué), ainsi que leurs fortes variations selon l'éclat de la région lunaire. Cependant les variations de la polarisation avec la longueur d'onde ne sont pas toujours respectées.

Des poudres de minérais clairs soumises à un bombardement protonique intense ou prolongé s'assombrissent. Il pourrait en être de même à la surface de la Lune sous l'effet du vent solaire. En collaboration avec le Dr J. E. Geake, à Manchester, nous avons noirci un échantillon pulvérisé de météorite achondrite à enstatite (Khor Temiki), par un bombardement protonique de 8 heures, sous $60 \mathrm{keV}$, la densité de courant étant $2 \cdot 10^{-6} \mathrm{amp} / \mathrm{cm}^{2}$. Les proportions de lumière polarisée relevée sur l'échantillon ainsi bombardé sont très différentes de celles de l'échantillon initial; elles deviennent semblables, sous tous les angles de vision,et à mieux que I millième, à celles observées sur les régions lunaires de pouvoir réflecteur $0 \cdot 145$. Les variations de la polarisation avec la longueur d'onde, entre 0.45 et 0.63 microns, deviennent également identiques à celles de la Lune. Cependant ce premier échantillon conservait un pouvoir réflecteur plus élevé que celui du sol lunaire de comparaison.

Comme il est possible que d'autres échantillons, en particulier parmi ceux mentionnés ci-dessus, donnent sous bombardements de protons des surfaces plus sombres, nous nous proposons de développer ces recherches.

D'autre part nous procédons à l'Observatoire de Meudon à l'étude polarimétrique de la Lune et d'échantillons minéraux dans l'infra-rouge jusqu'à $I \cdot I$ microns. Nous préparons un programme semblable pour l'ultra-violet jusqu'à 0.32 micron. Ces grandes extensions du domaine spectral de comparaison donneront des critères encore beaucoup plus précis pour la sélection des substances naturelles ou irradićes par protons capables de reproduire les propriétés photométriques et polarimétriques du sol lunaire.

\section{Electronic polarimetric images of the Moon}

\section{$V . P$. Dzhapiashvili and L. V. Xanfomaliti}

(I) Polarimetric observations of the Moon and planets have been carried out at the Abastumani Astrophysical Observatory (Georgia). The polarimetry is based on an electron polarimeter, the last model of which gives reading of degree of the plane of polarization, the angle and the stellar magnitude of the object (down to the $13^{m} \cdot 5$ using the $40-\mathrm{cm}$ refractor). Interesting results have been obtained with this device.

(2) Since 1962, observations of polarimetric images of the Moon have been carried out with a special device-an electron polarovisor, which is a scanning polarimeter.

(3) Polarimetric observations of the Moon in different phases permitted the detection of a class of objects on the lunar surface similar in shape to circi and craters, but not always spatially identified with them. The nature of these objects (for which the conventional names "polaro- 
circi' and 'polaro-craters' are proposed) is perhaps connected with the history of the Moon and results from the strained state of hypothetical glass-like mass accumulations or from the gas emission on the Moon's surface.

(4) As early as 1960 , the authors found that the polarimetry of the lunar surface near full Moon with the small polarimeter aperture $\left(\mathrm{I}^{\prime \prime} \cdot 5\right)$ shows the existence of small objects $(2 \cdot 5 \mathrm{~km})$ with very different physical properties.

(5) At the beginning of 1963 the second model of polarovisor was put in operation. With this device the effect of inversion of the polarization of seas and continents near full Moon was found.

(6) At present, the third model of electron polarovisor is under construction. This polarovisor will permit to improve the resolution of separate details on polarimetric images of the Moon. 